
$\$ B \quad 659464$ 

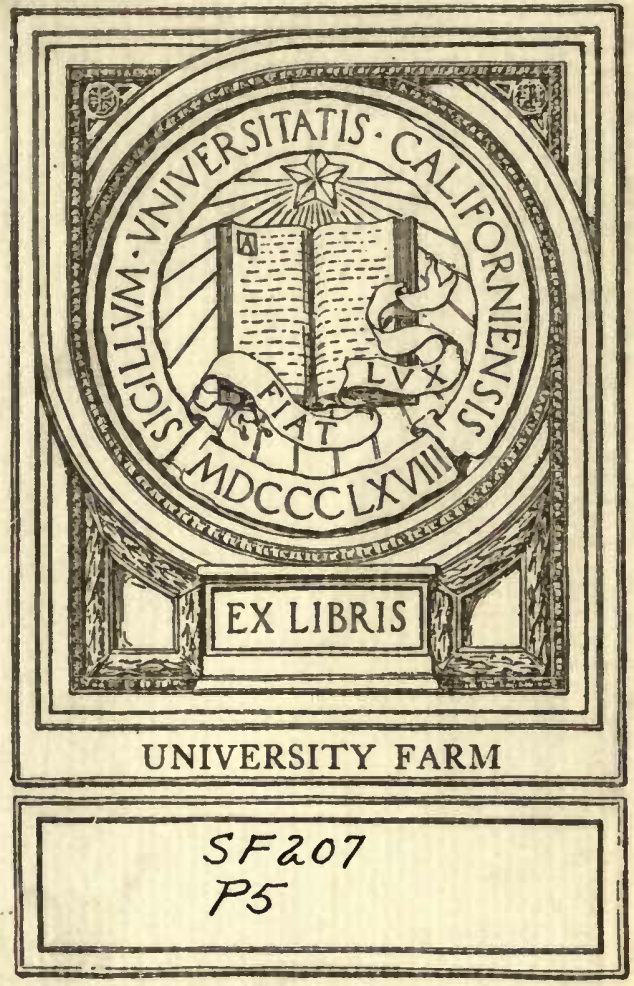






\section{Little Sketches of}

Famous Beef

\section{Cattle}

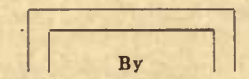

Charles S. Plumb, B. Sc.
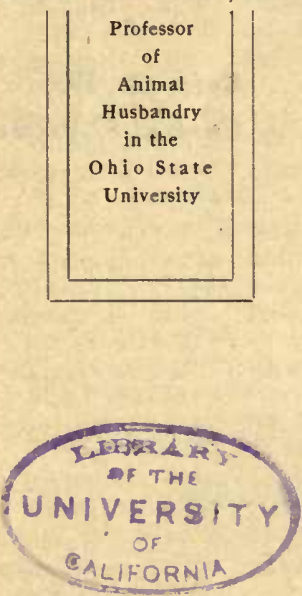

Columbus, Ohio

Published by the Author 1904

- 
UNIV. FARM

Copyright, 1904

by Charles S. Plumb

THE DROVERS JOURNAL PRESS

CHICAgO, $1 \mathrm{LL}$. 


\section{TABLE OF CONTENTS}

I Shorthorn bull "Hubback" (319) ............... 5

II Shorthorn bull "Favorite" (252) ............... 8

III Shorthorn cow "Duchess 1st" (E. H. B.) …........12

IV Shorthorn bull "Duke of Northumberland" (1940)...15

V Shorthorn cow "Isabella" (E. H. B.) …......... 18

VI Aberdeen-Angus cow "Old Grannie" (1) ..........21

VII Aberdeen-Angus bull "Panmure" (51) ...........24

VIII Aberdeen-Angus bull "Young Viscount" (736) $181 \ldots \ldots 28$

IX Aberdeen-Angus cow "Jilt" (973) $422 \ldots \ldots \ldots \ldots \ldots \ldots 32$

X Hereford bull "Sovereign" (404) $221 \ldots \ldots \ldots \ldots \ldots \ldots 36$

XI Hereford bull "Sir David" (349) 68 ............... 39

XII Hereford bull "Lord Wilton" (4740) 4057 ...........43

XIII Shorthorn bull "Champion of England" (17526) .......47

XIV . Shorthorn cow "Young Mary" 51

XV Aberdeen-Angus bull "Black Knight" (4751) .........55

XVI Hereford bull "The Grove 3d" (5051) $2490 \ldots \ldots \ldots .59$

XVII Shorthorn bull "Duke of Airdrie" (12730) 9798 ......6.62

XVIII Shorthorn cow "10th Duchess of Geneva" (E. H. B.) .....66

XIX Aberdeen-Angus bull "Abbotsford" (5411) 2702.....70

XX Hereford bull "Dale" $66481 \ldots 74$

XXI Shorthorn bull "Gay Monarch" $92411 \ldots \ldots \ldots \ldots \ldots 78$

XXII Hereford bull "Corrector" 48976 ............... 82

XXIII Shorthorn bull "Young Abbotsburn" 110679 .......86

XXIV Aberdeen-Angus cow "Lady of Meadowbrook" 21466....91

XXV Galloway bull "Scottish Standard" (6488) $15221 \ldots . . .95$ 


\section{PREFACE}

This series of sketches of beef cattle was originally published in THE CHICAgo DaIly Drovers Journal under the title of "Little Sketches of Famous Cattle." They were written at the request of the publisher of that excellent journal, and were intended mainly for students in animal husbandry, such as are found in our agricultural colleges, and for such readers as were interested in breed history. As the title implies, these sketches were not intended to be extended studies of individuals and their varying relations to the breeds, but were, rather, life sketches giving the more important reasons why the animals discussed became famous. Each animal may be regarded as a really famous one, with important historical breed connections. There are hundreds of other famous animals distributed through a century of Shorthorn, Hereford, Aberdeen-Angus and Galloway history. Some of these are clearly entitled to a place in the history of beef cattle immortals. Nevertheless, the twenty-five sketches following in this volume are of animais that have piayed most important parts and are cleariy entitled to the prominence here given them.

In sketches of a number of animals like these, with so many associations connected with their various careers, it is but natural that errors should occur to some extent. The author, however, has made every reasonable effort to be careful in statement, and it is believed that these sketches can be regarded as fairly free from error and prejudice of expression.

C. S. PLUMB,

Ohio State University, College of Agriculture.

April, 1904. 


\section{H U B B A C K}

In some respects this is perhaps the most famous animal in cattle history. This is due to the fact that many have regarded him as the first great breeding bull of the Shorthorn class of cattle. His career was unique and almost without a parallel, which rather adds to his historic interest.

The Shorthorn breed came to its own up in northeastern England, in a beautiful grazing region, particularly in the counties of Yorkshire and Durham. For many years along in the eighteenth century cattle of the Shorthorn type, of much excellence, were bred in this part of England, along the valley of the Tees, from which they at first derived the name "Teeswater cattle." Dutch and Galloway blood were used somewhat in early times on these Teeswater cattle, but it is also probably true that there. were heras bred with fair purity for many years, from which the genuine Shorthorns of to-day are descended.

The early type of Shorthorn, we are told, was rather large and rangy and lacked quality, and did not represent the best stamp of the feeder.

About the middle of the eighteenth century a brlcklayer named John Hunter was a tenant farmer in the County Durham. About 1771 he left the farm and moved to a little village near the city of Darlington, named Hurworth. He had sold all his cattle excepting one beautiful Shorthorn cow, which he brought with hirn to his new home. Owning no land, he was obliged to graze her along the roadsides. In 1777 she dropped a bull calf, to a pure Shorthorn bull, owned by George Snowdon of Hurworth. It is this bull calf which afterward attained so much fame.

When yet a calf Mr. Hunter took the cow and son to Darlington market and sold them to a Quaker, who the same 
day sold them to a Mr. Basnett, a timber dealer. Ownership of the calf was later transferred to William Fawcett, near Haughton, in the same nelghborhood. Here he came into active service and was used about three years by Mr. Fawcett, he charging a service fee of 1 shillIng, or about 25 cents American money.

Among the early Shorthorn breeders of this time and in this vicinity was a Mr. Waistell and Robert and Charles Colling. Walstell and Robert Colling, on Good Friday, 1783, visited Mr. Fawcett and tried to buy this bull. The prlce was 10 guineas, and they offered 8, which was refused. On the next Sunday Mr. Waistell visited Fawcett and bought the bull at the price asked. Returning home, he met Robert Colling of Barmpton and told him what he had done. Then Colling agreed to pay half, and thus have a partnership in the bull, which was accepted. These two used the bull during the summer of 1783 , on about twentyeight cows. In November, that year, they sold him to Charles Colling of Ketton for. 8 guineas, and it is claimed that Mr. Waistell was to have service for his cows as long as Charles Colling owned him. In February, 1784, Waistell sent a cow to be bred, and colling returned word the service fee would be 5 guineas, with which Waistell indignantly ordered the cow home unserved. Colling kept this bull for two years in his herd, and then sold him to a Mr. Hubback of Northumberland, from whom the bull derived his name. He was used in service by Mr. Hubback until 1791, and was vigorous to the last.

Hubback was yellow-red and white, and history tells us that he was of the smaller, short-legged, thick fleshed type. Coates described him as having the following quallties: "Head good, horns small and flne, neck fine, breast well formed and fine to the touch, shoulders rather upright, girth good, loins, belly and sides fair, rump and hips extraordinary, flank and twist wonderful." He was the last calf of his dam. She would not breed again and was sold to the butcher. She has been generally regarded as a cow of great handling quality. The quality of Hubback was no doubt inherited from his dam.

There is some difference of opinton as to the greatness of Hubback as a sire. 
For years he had no distinction as a breeciing bull. This was later discovered by the Colling Bros. after he had passed from their possession. For years he was what would be regarded as most peculiar to-day-a nameless bull. $\mathrm{He}$, however, left at Ketton a heifer called Haughton. She was bred to Richard Barker's bull (52), from whlch came the bull Foljambe (263). This latter was bred to a number of Colling's best cows, including a red-roan heifer, Lady Maynard, and she dropped a helfer called Phoentx. Another daughter of Lady Maynard named Young Strawberry was bred to Foljambe, from whence came the bull Bolingbroke (86), an animal of rare merit. Here Colling began to inbreed, mating Bolingbroke to Phoenix. froni which came the bull Favorite (252), one of the most extraordinary of Shorthorn sires in past history.

There has been more or less of controversy over the purity of the ancestry of Hubback, but the best evidence has it that he came of pure Shorthorn blood. Through his prepotency the Colling Bros. developed Shorthorns to such a perfection that they are frequently referred to as the founders of the true Shorthorn and Hubback as the foundation sire. Thomas Bates, the peer of any Shorthorn breeder of the past, who had seen Hubback and his get, sald: "It was the opinion of all good judges in my early days that had it not been for the bull Hubback and his descendants the old valuable bieed of Shorthorns would have been entirely lost, and that where Hubback's blood was wanting, they had no real merit, and no stock ought to have been put in any herd book of Shorthorns which had not Hubback's blood in their veins." Bates laid great stress on his superior quality as a feeder, and he also regarded his handling as better than any bull of his day.

No doubt Hubback imparted to his descendants much of his compactness of form, his superior capacity to lay on flesh evenly all over, and his remarkable general quality. He may not in truth have been the greatest bull of his time, but so far as history tells us, there Is no record of his equal. Further, it will not be a difficult task after these 125 years to trace back the pedigrees of many Shorthorns of to-day into the blood of old Hubback. 


\section{FAVORITE (252, E. H. B.)}

The practice of in-and-in breeding does not meet with the approval of the most careful students of live stock husbandry. Its persistent use is attended with serious injury. It is interesting, in this connection, to note that the Shorthorn bull Favorite (252) was apparently an exception to this rule, as he was a result of its application. Not only was he an example of in-and-in breeding, but he was bred to his own mother, daughters and sisters and descendants to such a degree as had heretofore been unheard of.

Charles Colling of Ketton, England, becomes a character in history as a really distinguished breeder of Shorthorns. By many he and his brother Robert are desIgnated as the first great improvers of the breed. Be that as it may, they certalnly were the first to become famous for breeding Shorthorns of marked merit by the process of in-and-in breeding.

Favorite was dropped in 1793. His dam was named Phoenix, and she was a daughter of the bull Foljambe (263), while his sire was Bolingbroke (86), a son of Foljambe. The dam of Foljambe was by Hubback. Favorite was used in the herd of Charles Colling for many years, with remarkable results. He lived to a ripe old age, dying in 1809, aged 16 years. Favorite was a rather large bull of a light roan color. Both Coates and Walstell classed him as very superior. The latter referred to him as "a graind beast, very large and open, had a fine brisket, with a good coat, and as good a handler as was ever felt." The dam of Phoenix was a very large "open-boned cow, coarser than her' dam, 'the beautiful Lady Maynard.'" Favorite probably more resembled his dam than grandam.

Great fame early came to Favorite from his being the sire of two wonderful 
beef cattle, the "Durham ox" and "the white heifer that traveled." The former, from a grade cow, was bred in 1796, and was among the first calves got by Favorite. He was steered when a calf and was fed most skillfully by Colling. When nearly 5 years old he weighed 3024 pounds, and was sold for exhibition purposes. He was exhibited in a traveling carriage, and with such success that various offers for him were refused, up to $\$ 10,000$. He toured England and Scotland for nearly six years, when, because of an. accident which dislockted his hip, he was killed. He dressed 2620 pounds. At 10 years old he weighed 3400 pounds.

In 1806 Robert Colling had a pure-bred Shorthorn heifer dropped, that was sired by Favorite, and was white in color. She was a twin with a bull calf, and did not breed, but became very large and fat. She was exhibited at many fairs, and became known as "the white heifer that traveled." It is said that she welghed about 2300 pounds alive, and it is estimated that in the dressed carcass she weighed about 1800 pounds.

Charles Colling desirea to concentrate good blood in his herd, as much as possible, so he began in-and-in breeding, with a limited number of animals, with Favorite as the central figure.

'Two things conspired to make Favorite a famous bull. First, because he was the main factor in Colling's most unusual process of in-and-in breeding, and, second, because his sons and daughters and descendants became among the most famous animals of their generation.

Charles Colling was a most discriminating judge of cattle. He sought to secure beauty, quality and early maturity, with light waste at slaughter. Referring to the method of breeding followed by Colling, the Rev. J. Storer makes interesting discussion of it in "Carr's History of the Booth Shorthorns." He says: "Mr. C. Colling's bull Bollngbroke, and his cow Phoenix, were brother and sister on the sire's side and nearly so on the dams'. They were of the same family, and the only difference in descent was that Bolingbroke was a grandson of Dalton Duke, while Phoenix was not. But this apparent difference, slight as it is, was not all real, for Dalton Duke also contained some portion of their common blood. Arithmetically stated, the blood of the two being taken 
and divided into thirty-two parts, twenty-nine of those parts were of blood common to both, rather differently proportioned between them. Phoenix had sixteen of those parts, Bolingbroke thirteen, the latter having also three fresh parts derived from Daiton Duke. which made up the thirty-two. Being thus very neariy own brother and sister, they were the joint parents of the bull Favorite. That bull was next put to his own mother, Phoenix, so nearly related to him on his sire's side also, and the produce was Young Phoenix. To this heifer Favorite was once more put, she being at once his daughter and more than his own sister, too; for their two sires, Bolingbroke and Favorite, were not only as nearly as possible consanguineous with each other, but also with the cow Phoenix, to which they were both put. The result was Comet (155.) Nor was this all. The system was carried much further. The celebrated Booth bull Albion (14) was not only a son of the in-and-in Favorite-bred Comet, but his dam was a granddaughter of Favorite on both sides, and descended besides from both the sire and dam of Favorite."

Favorite was used very extensively on his own offspring, and sired numerous famous animals, among which may be mentioned the Durham ox, the White heifer, Comet (155), Daisy buil (186), Young Phoenix, Laura, Johanna, Cherry, Red Rose, Moss Rose, Juno, Marske (418), North Star (459), Styford (629) and Ketton 1st (709).

At the dispersai sale of the charies Colling herd in 1810 there were sold forty-seven cattle, three-fourths of which were got by Favorite or Comet (155), his son, and the balance of the herd by bulls of their get. Colling during his later çareer found it necessary to introduce new and foreign blood into his herd, to renew the constitutional vigor, and so the famous "alloy" or Galloway blood was used. Yet the sale was a great success, in spite of the prejudice which existed against the intense in-and-in breeding practiced by Colling. The forty-seven head sold brought an average of about $\$ 750$ each, while Comet, Favorite's son, made the record high price up to that time of $\$ 5,000$.

In Lewis F. Allen's "Pedigrees of English Shorthorn Bulls to Which American 
Shorthorns Trace" the records show thirty sons of Favorite to be recorded in volume 1 of the Coates herdbook. A large number of his other descendants are also registered therein. In fact, as expressed by A. H. Sanders, in his work on "Shorthorn Cattle," "his get were not only the most celebrated Shorthorns of their day, but his immediate descendants constitute a large percentage of the entire foundation stock upon which the herd book records stand." Most certainly Favorite is entitied to a very prominent place in Shorthorn history: 


\section{DUCHESS ISt (E. H. B.)}

Shorthorn cattle predominate among the beef breeds in English-speaking countries. So extensively have Shorthorns become distributed that they have been termed the "universal intruders."

Among Shorthorn cattle no family in its past history has received so profound attention, none has sold at such high prices as that known as the Duchess. There have been other famous Shorthorn families, and perhaps better ones. Who knows? But certain it is, never has greater fame ever come to a family of any breed of cattle than to the Duchess of the Shorthorns.

Tradition has it that for 200 years cattle of this particular strain had been bred on the estate of the Duke of Northumberland in northeast England. But this is tradition only. History, however, takes us back to 1737 , to a red bull calved that year, later known as James Brown's Red Bull (97). In 1784 Charles Coliing bought in Darlington market a cow which he named Duchess. She was from the Stanwick estate of Sir Hugh Smithson, who later became the Duke of Northumberland. She was also known as the "Stanwick Duchess" and the "Stanwick cow." It is claimed that. she was sired by James Brown's Red Bull, which from the years intervening is very questionable. This cow was later mated to Hubback (319), and from her came a helfer and a continuation of Duchess blood. This stock seemed to meet the approval of Thomas Bates, who at that time was in the early stages of his career as a Shorthorn breeder. In or about 1804 Bates purchased for about $\$ 500$ from Colling a granddaughter of the Stanwick Duchess, named Duchess, by Daisy Bull (186), 4 vears of age, and out of a cow by Favorite (252), and in calf to Favorite.

Duchess, by Daisy Bull, did not produce any heifers while owned by Bates. In 1805 she dropped the bull calf Ketton (709), that later became famous. She had, however, left a helfer in Colling's herd at Ketton. This was bred to Comet (155), a son of Favorite, and from which resuited a heifer calf, that was first named Young Duchess. 
Bates early became convinced of the superior merit of this Duchess blood. The orlginal old Stanwick Duchess was described as a "massive, short-legged beast, breast near the ground, a great giower, with wide back and a beautiful yellowish-red flaked color." The Duchess cow was a disappointment to Bates, so at the closing-out sale of Charles Colling in 1810 he determined to secure the red and white heifer Young Duchess, by Comet. Being afraid that the bidding would be carried too high if he bid in person, Bates shrewdly employed another to make the bids on the Young Duchess. Thus he obtained her at 183 guineas (about \$900). When the Collings learned that Bates was the purchaser it is stated that they felt much incensed, and Mrs. Colling is reported to have declared that had they known it was Bates' bid the heifer would have cost him two or three times as much before he could have gotten her. She was not exactly one of the plums of the sale, and the people about Halton castle, at that time the home of Bates, rated her as "shabby." The father of Bates ridiculed the purchase of the son.

The heifer purchased as Young Duchess Bates named Duchess 1st, and inasmuch as this distinguished breeder created and developed this family, she may be regarded as its foundation dam. "Colonus," writing of her in 1882 from hitherto unpublished manuscript notes made in 1819-20, comments on her as follows (National Live Stock Journal, page 460): 'Mr. Bates' Duchess 1st has good head, horn, sides and flank; was only falr in shoulder points, loin, quarter and touch. Her daughter, Duchess, 2d, by Ketton (who was of Hubback's colo: yellow red), was only fair in all the above enumerated points. Duchess $3 d$, also out of Duchess 1st, and got by Ketton 1st, had a good head, horn, shoulder, loin, slde, flank, quarter, and touch."

Bates had great faith in Duchesses. In 1842 he wrote: "I selected this tribe of Shorthorns as superior to all other caltle, not only as small consumers, but as great growers and quick grazers, witis the finest quallty of beef." The cows of this family were especially famous as large producers of milk, a feature Bates repeatedly referred to as a point of merit.

Duchess 1st is especlally entitled to fame as the substructure upon which Bates worked to build up the family of 
this name. Her field was not in the show yard. There are other Duchesses that have acquired much more personal fame, notably Duchess 34 th, Duchess 38 th, and Duchess 43d. There was a long line of sixty-four Duchess females between 1808 and 1849 , when the chapter closed with Mr. Bates' death. They were the result of intense in-and-in breeding, and became notorious for being unprolific so long as untouched by other blood. Unquestionably they had merit, while some of the bulls of this family and notably Duke of Northumberland (1940) met with the high approval of the critics.

Duchess 1st produced down to 1819 four females, viz., Duchess $2 d, 3 d, 4$ th and 5th, and one male, Cleveland (146) Mr. Bates at one time desired to breed Duchess 1st to Robert Colling's "White Bull" (151) and offered him a service fee of $\$ 500$, which was refused. This bull was of the Princess famlly, whlle all of the five offspring of Duchess 1st. were strongly in-and-in bred. Duchesses.

Duchess 1st pased the way of all fiesh, but she is destined to live long in history as an important factor in the development of the nineteenth century short.horn as exemplified by Thomas Bates. 


\section{DUKE OF NORTHUMBERLAND \\ (1940 E. H. B.)}

There comes a time in the life of every breeder of eminence when he reaches his highest degree of success by the production of one individual most representative of the lofty ideals of the critic. Thus the Duke of Northumberland appeared as the crowning triumph in the life of Thomas Bates.

The Duke of Northumberland (1940) was calved Oct. 15, 1835. He was sircd by Belvedere (1706) and Duchess 3ith was his dam, she being also sired by Belvedere. On the maternal side, in a cirect line of descent, Duchess 23 th was erandam, Duchess 20th great grandam, Duchess 8 th-great-great-grandam, Duchess 2a, great great great grandam, and she out of Duchess 1st. Belvedere, one of the really great bulls of his time. was descended four generations from the cow Princess, by Favorite, a cow of rare character, whose breeding Bates most highly esteemed. While Duke of Nortlilimberland is thus a distinctively Duchess bred bull, unquestionably the blood of Princess played a significant part in his make-up, as Bates intended that it should. A careful study of the Duke's pedigree for seven generations, however, shows the necessary general pedigree strength to create the individual of rars quality and character.

The dam of the subject of this sketch, Duchess $34 \mathrm{th}$, was an animal of remark: able quallty and conformation, and was one of the first show cows of her time, defeating the renowned Necklace of John Booth at the Royal show at York, Fingland, in 1842. Duke of Northumberland was a red roan in color, and he was given this name by Mr. Bates "to peryetuate the commemoration that it is to the judgment and attention of the ancestors of the present Duke of Northumberland that this country and the world are irdebted for a tribe of cattle which Charles Colling repeatedly assured me was the best he ever had or ever saw."

As we go back in the early history of breeling cattle we find that the practice of public exhibition and competition was comparatively recent. Many fumous animals were never seen in the show ring. They, however, were known to be of cor- 
rect type, and they secured fame by thelr prepotency. The Duke of Northumberland, however, had much fame in the show ring. Mr. Bates did not exhlblt his cattle often, but he appeared on various occasions with representatives of his herd. In 1838, at the Yorksnire show, the Duke won first place in a class of elght 2-year-olds. In 1839 at the firs: annual show of the Royal Agriculturai soclety, held at Oxford, he was first in a class of seven. Referring to that show, George Drewry, late herd manager of the Duke of Devonshire, after fifty years wrote: "The two things that I remember best at Oxford were the Duke of Northumberland and Duchess 43d. These, I still think, were the two best Shorthorns I ever saw."

Ar interesting incident occurred while the Duke was being transported to $\mathrm{Ox}$ ford. He was shipped by steamer from Middlesborough to London. The story is told that in endeavoring to lead the Duke on the gang plank from the steamer to the wharf, he slipped and fell across the gangway, where he lay. Bates rushed to him and began patting his hєad, exclaiming: "Poor boy! poor boy!" There he remained until relleved, and fortunately no harm was done.

In 1839, referring to the Duke of Northumberland, Bates wrote: "I can state fron measurements I took of the celebrated Comet (155) that the Duke was nearly double his weight both at 10 months and at 2 years old."

In the summer of $1841 \mathrm{~A}$. B. Allen of New York made a visit of a week with Mr. Bates at his home at Kirklevington. In a most interesting serles of letters on this visit (National Live Stock Journal, 1884), Mr. Allen gives speclal attention to the Duke of Northumberland. $\mathrm{He}$ made careful measurements of his body, assisted by the herdsman, Tommy Myers. $\mathrm{He}$ stood five feet high at the withers, was elght feet four inches long from the base of the horn level to the end of the rump, at the joining on of the tail, and girthed elght feet behind his shoulders. His welght was estimated at 2300 pounds.

The general testimony of the critics is that.this bull was a magnificent specimen of the breed. Mr. Allen's reference to him is worth quoting: "At the opening of the door to the stall of the Duke of Northumberland, he made a bound outside, with the agillty of a deer, stood still and stared at me a moment, and then com- 
menced capering about like a high-spirited Arabian horse, strongly reminding me, in his action, fine points and harmonious make-up, of what I had seen of these high-cast, noble animals. Then, as he became more quiet, and was led around by the herdsman, I increasingly admired his free, easy grace of movement and imposing presence; and after thoroughly examining him from day to day during my stay at Kirklevington, I could but come to the conclusion that he was the most perfect and magnificent animal of his race, which, up to that time, had come under $m y$ observation. Fisher Hobbs, a Booth man, and consequently not prejudlced in favor of Bates stock, as well as other distinguished breeders, pronounced the Duke of Northumberland the best bull of his day in all England, and I belleve no one has yet gainsald that decision."

The Duke was especially commended for his high-bred, masculine head, breadth and depth of chest, full crops, and round, level carcass. He was good In loin and quarter, and strong in the twist. His handling quality, hair and skin were first-class.

This bull was great as an individual, but he also had merit as a breeder, although he cannot be considered the equal of either Belvedere or-cemet in that respect, both of -which owned by Bates. The Duke was born, lived and died the property of Bates, and history has it that large sums of money were offered in exchange for the bull, but the owner was not tempted.

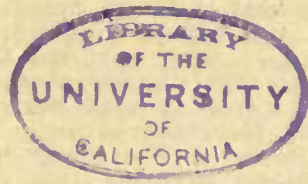




\section{IS ABELLA}

The Booth family began its career in breeding Shorthorns with Thomas Booth at Killerby, Yorkshire, England, about 1790. He had two sons, Richard and John, who inherited the family estate and established separate herds of their own. In 1814 Richard left Killerby and took the Studley farm at Ripon, where ie continued breeding until 1834, wheil the herd was dispersed.

Within a year after locating at Studley Mr. Booth bought in Darlington market a roan cow. She was sired by Mr. Burrell's bull Burdon (1768). Bred to Agamemnon (9), this roan cow produced a heifer which is known as the "white cow." At that period there were two bulls in the herd of Thomas Booth at Killerby, viz., Albion (14) and Pilot (496). Both of these proved animals of great breeding character. In fact, Albion was regarded as the greatest of the Booth bulls of early days. The "while cow" was bred to Pilot, from which union came the heifer Isabella, the subject of this sketch. This "white cow" was also the dam of Own Sister to Isabella and Lady Sarah. The former was dam of Blossom, and she was dam of Medora, "one of the neatest cows Mr. Eooth ever bred."

History records many famous breeding beef matrons, but for general excel$l \in$ nce and extended usefulness Isabeila niay be classed among the very first. She was not only an animal of great individual merlt, being termed the "matchless Isabella," but she proved herself to be a breeder of the first class, and from her came the Isabella tribe, one of the very best of Booth breeding. To illustrate the superior qualifications of Isabella as a show cow, the following is pertinent: Sir Charles Morgan in 1823 proposed a trial of merlt between Shorthorn and Hereford cattle. The Rev. Henry Berry, a Shorthorn advocate of note, wished to bring this competition about and proposed that such a contest take place on the following Christmas. He offered to place tw'o Shorthorn females agalnst any two Herefords in England of similar age and fecundity. One of these two was Isabella, then 3 
years old. She was Mr. Berry's ideal Shorthorn. The ofler made by the parson was never accepted.

Carr, writing in 1867 of the Booth Shorthorns, says that Isabella and her descendants brought the massive yet exquisitely molded forequarters into the herd. Isabella's grandam was very strong in the development of this part. She was also responsible for the stralgh: underline, a feature of this tribe. This writer further states that the Isabellas all had great capacity for rapidly acquiring ripe condition on pasture. The story is that at one of the Yorkshire agricultural meetings a grass-fed heifer. a daughter of Isabella, sired by Ambo, was rejected by the judges as too fat. As she did not breed she was slaughtered at York for Christmas beef. Her two successful rivals also were nonbreeders, and, as it happened, they were slaughtered at the same time and place, and then it was clearly shown that the Isabella heifer had the best carcass and was awarded the dressed beef prize.

According to the Coates herd book, Isabella was calved May 17,1820 , and between 1823 and 1834 was the dam of nine calves, six of which were females. Her first calf was a roan heifer, that was also named Isabella. In 1825 she had a roan bull calf, that was named Isaac, by Young Albion (15), that proved later to be a valuable sire, although, unfortunately, he was killed before his real worth became known. In 1828 or 1829 she had another roan heifer calf, that was named Young Isabella, by Memnon (2295). and in 1833 a red and white heifer by Burley (1766), named Isabel, was dropped. These are only a portion of the calves she was dam of up to and including 1834. That year Richard Booth's herd was sold at a dispersion sale. But he did not sell everything under the hammer. He retained one cow only of the entire herd, and that was Isabella. Removing the year of the sale temporarily to Sharrow, and after a year's resi. dence there to Warlaby, Richard Booth took with him this great dam, whlch at this period was termed by one writer "a large, patchy cow."

The first year at Warlaby Isabella produced a roan bull calf, by Young Matchem (4422), after which, in her eighteenth year, by the same bull, she dropped a heifer that was named Isabella Matchem. This heifer proved, like her dam, to be very prolific, and was the mother of a 
number of famous sons and daughters, including Fitz Leonard (7010), Vanguard (10994), and the roan helfers Innocence and Isabella Buckingham. The latter, in her time, was a famous show cow, being celebrated for victories won at the Royal in 1846 at Northampton, and in 1847 at York, winning second place in 1848 at the Norwlch Royal.

In early days at Killerby was another famous cow, slred by Pilot, the sire of Isabella, Anna by name. Her son, Argus, and Isabella's son, Isaac, were used on the herd, and from their blood came the cow Toy, a daughter of Argus, and the bull Priam (2452), a son of Isaac. A mating of Toy and Prlam produced the famous twin heifers Bracelet and Necklace, no doubt the most remarkable Shorthorn twins in English history. Isabella Buckingham was sired by a son of Bracelet by the name of Buckingham (3239), a combination of the choicest Booth families. "The 'imposing grandeur' of the Warlaby Isabellas," says Sanders, "was a theme upon which admirers of the herd ever loved to dwell, and Isabella Buckingham of that line, like Charity, reaped a rich harvest of ribbons and rosettes."

But few cows live to such a ripe old age as did Isabella. What a record! Eighteen years of noble service in giving her life blood, that the name and fame of Booth Shorthorns might be perpetuated. And down through the generations the blood of Isabella has fulfilled the highest mission of her kind, thereby entitling her to a place in the Shorthorn hall of fame, if such there be. 


\section{OLD GRANNIE (I)}

All references to early AberdeenAngus history pay deference to the cow Old Grannie, bred by Hugh Watson of Keillor, Scotland. And well they may. So far as the writer is aware, she stands without an equal in years and usefulness. In the Scotch Polled Cattle Herdbook, in the first volume issued, which combines both Aberdeen-Angus and Galloway, is Old Grannle (1), or the Prima cow. Calved In 1824, she died on July 1 , 1859, at the age of 35 years and 6 months.

Scotland has produced in the past a number of celebrated breeders of Aberdeen-Angus cattle, and in their time none gave greater service to promoting high-class breeding than Hugh Watson of Keillor, Forfarshire, William McCombie of Tillyfour and Sir George Macpherson Grant of Ballindalloch. The tirst two long since passed away, but the latter is yet an active breeder.

Old Grannie was one of the most notable of many noted animals bred by Watson. It is said that he desired to keep her as long as possible, to demonstrate the longevity of a vigorous animal of the breed kept in a natural condition. And so during the many years of the triumphs of Watson, Old Grannie stood at the head of the herd as an example of what an Angus matron might do and be.

In her long career she produced twenty-five calves, of which eleven are registered in the herdbook. The following list gives their names and sires:

BULLS.

Strathmore (5) ........................... 1851

Old WIndsor (115).................... Bire, Bituek Jock (3)

First Mlemus (129) .............. Sire Black Jock (3)

Hugo $(130) \ldots \ldots \ldots \ldots \ldots \ldots \ldots \ldots$. Sire, old Jock (1)

The Baron $(134) \ldots \ldots \ldots \ldots \ldots$........... Black Jock (3)

cows.

Hope (3).............. Sire, Grey-Breasted Jock (2) Lady Clara (4)............... Sire, Grey-Breasted Jock (2) Beauty of Buchan (5)... Sire, Grey-Breasted Jock (2) Young Favorite (61)... Sire, Grey-Brea'sted Jock (2) Fdinhurgh (64) ......... Sire, Grey-Breasted Jock (2) Kelllor (231).................... Slre, Old Jock (1)

If it is true that the real history of the Aberdeen-Angus breed began in 1808, with the improvements of Watson, then this work had been sixteen years in 
progress when Old Grannie entered in on the scene. During the first twentynine years of her life she produced the twenty-five calves, after whlch she ceased breeding. In fact, after her twenty-elghth year she produced no milk for the calf to suckle.

This cow had more merlt than simply age and fecundity. Mr. Watson valued her offspring, and they became important factors in his herd. Some of her daughters were purchased by the best Scotch breeders. Mr. Ferguson of Kinnochtry bought in 1839 Young Favorite (61) and Edinburgh (64), and Mr. McCombie of Tillyfour bought Lady Clara (4). In 1882 Macdonald and Sinclair wrote: "The blood of Old Grannie (1) circulates in the male line in many existlng tribes of cattle, and she has also several living female descendants." Through the work of Mr. Ferguson, resulting from his 1839 purchase of Young Favorite (61), came the Princess and Baroness families, while Edinburgh (64) became the foundress of the Emlly family. There is little, difficulty in tracing back Angus pedigrees of to-day into the dlrect blood of old Grannie.

Some of the unregistered offspring of this old matron were also highly esteemed. A son of hers, that later came into service as an ox, Hugh Watson considered the most perfect specimen of the polled breed he ever ralsed. This ox won first prize in class in 1843 at the Highland show at Dundee, and he walked the thlrteen miles from Kelllor to the grounds to be exhibited. At Belfast, Ireland, Prince Albert, husband of Queen Vlctoria, purchased him, and, as his property, showed him at Smithfield in 1844 . This ox met with such favor in the royal family as to be made a llfe pensioner.

A painting was made of him for $\mathrm{Mr}$. Watson, and colored engravings were also published and widely distributed, one of which is in the possession of the writer. A portrait was also made of him by the celebrated animal painter, Gourlay Steell. This ox served as a valued laborer on the farm and lived to be 17 years of age.

In searching for specific information concerning old Grannie, the writer has been unable to find any statement as to her type and personal character. 'No mention of these things is made in considerable Angus literature at my dis- 
posal, including articles by Hugh Watson himself, William Watson, his son, and an extended sketch by a daughter, as well as the writings of McCombie, Macdonald and Sinclair and R. C. Auld. That she was an animal of very superior form and quality in her prime is undoubted. Miss Watson writes of Old Grannie: "She, herself, when she was 34 , was shown at Aberdeen as extra stock in 1858, and created quite a sensation in the show yard." The sensation, however, was no doubt due to the remarkable age of the cow herself. As she was the dam of over two dozen prize-takers, she no doubt had the essentials of a shapely cow of quality.

Aside from the breeding value of old Grannle two things occurred during her life that add much interest to her career. In 1859 , two days before her death, at the special request of Prince Albert, a photograph of her was taken, and in October, that year, was placed in the collection of cattle photographs in Balmoral castle, the Scotch home of the queen.

Another happy incident was the presenting to James Thompson, the herdsman who had attended old Grannie all lier life, who had been in Mr. Watson's employ for forty-two years, of a medal and premium of 100 francs by the French Soclety for the Prevention of Cruelty to Animals. This was in recognition of the kindness whlch must have characterized the care of the old matron during the many years of her life at Kelllor.

There must have been many a tug at the heart strings when Old Grannle passed away on that July 1, 1859. And, as many an old granny leaves a vacancy hard to fill in this world, so. must this old dame have left at Keillor a place none but she could occupy. Nor was there another like her, at least in that bonnie Scotlanr. 


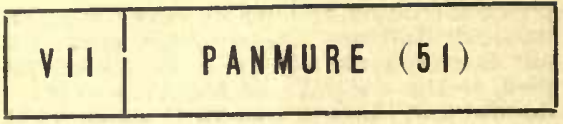

The breeder of Aberdeen-Angus cattle who does not study pedigrees may have to plead guilty of lack of knowledge of Panmure (51), and yet in his time he was a very famous animal. In fact, by many he is regarded as important an element in Angus history as Hubback of the Shorthorns. Both were great bulls Individually and in breeding power.

There has been some controversy concerning the ancestry of Panmure. Vol. I. of the Scotch Polled Cattle Herd Book states that his dam is Black Meg (766), an animal of implled Galloway blood, while the name of her sire is not given in this volume. A careful study of the parentage of Panmure was made by $\mathbf{M r}$. Jamleson of Marischal college, Aberdeen, who most satisfactorily solved the question. Black Meg (766) may be referred to as Black Meg of Ardovie. William Fullerton of Ardovie, the owner of Panmure, in correspondence published by Mr. Jamieson, states that the bull was bred by Lord Panmure, and that his dam was Black Meg of Panmure, unquestionably an Aberdeen-Angus. Some time after the publlcation of the herd book referred to it was learned that Panmure was sired by an Angus bull by the name of Hector, bred by a gentleman of that name of Fernyflatt, parish o1 Iinneff.

Regarding the reflection on the purity of Panmure's breeding - that is, being partly from Galloway blood-the following is of interest: 'Tre bull was owned for some years by Mr. Farquharson Taylor of Wellhouse, Aberdeell. While in his possession Lord Panmure sent a famous artist by the name of Phillip to his home to paint the bull's portrait. "Not satisfied with Mr. Phillip's first sketch," writes Mr. McCombie, "he sent him back and Mr. Phillip lived at Wellhouse for weeks and painted Panmure a second time." Referring to the portrait of the bull, as bearing on breed ancestry and type, Mr. Fullerton, along in the early ' 70 s, wrote to Mr. Jamieson as follows: "But the bull Panmure is on canvas in the Mechanles' hall, Brech- 
in, painted by the great 3 . Phillip; aiso he is now before me, and on canvas by the same great man, and presented to me by the late Lord Panmure; and let any judge look at these paintings and say if he sees the very slightest resemblance to the Galloway breed. Not he! No? Half a judge would even say so. His elegant head and stately outline would at a glance at once bring out such a remark as, "There has been no Galloway" blood there-No, no!" "

Mr. Fullerton was a celebrated breeder of Angus cattle in his time, winning many prizes of great value. Panmure was calved in 1840 , and in 1841, when a year and a half old, he was purchased by Mr. Fullerton from Lord Panmure for about $\$ 90$ American money. He proved to be a good investment, although owned by Mr. Fullerton but two years. While in his possession he sired Monarch (44) and another bull named Colonel. Panmure was exhlbited by Mr. Fullerton and with much success, winning the first prize as a 3 -year-old at Dundee in 1843, when in very strong competition. After this show he was purchased by Mr. Taylor, already referred to, in whose hands he made a good record as both breeding and show bull. Referring to him in his later career Mr. Fullerton writes: "I saw him (Panmure) stand as winner of the third prize at Aberdeen with his two sons, Monarch (44) and the Colonel, both bred by me, standing beside their father-Monarch having the first and Colonel the second prize. Of course Panmure was by this time some 8 or 9 years of age, and so wanted to some extent the outline and sprightliness of a 3 or even a 5 year old. Still, and to make allowance for the service he had rendered, there would have been but small mistake, if any, to have made his sons stand below him. I do not think I have ever seen such a dashing 3-year-old as he was at Dundee in 1843."

Eleven calves of Panmure are recorded in the first volume of the Scotch herd book, but it is known that he was used liberally in the localities where owned and he no doubt slred many calves that were never registered. Some of the more important ones recorded are Monarch (44), Princess (47), Jean Ann (206), Queen Mother (348), Queen of Scots (72), Queen of Kinnochtry (572), and Princess Daughter (832). 
Panmure, bred to Queen of Ardovie (29), a daughter of Black Meg (766), produced Queen Mother (348), the foundress of the famous Queen tribe, most highly esteemed by all lovers of Angus cattle. Monarch (44) was a son of Panmure's through a daughter of his by the name of Julia, out of Susanna, a daughter of Black Meg (766). Thus Monárch and Queen Mother, as a result of in-and-inbreeding worthy of a Colling, were half brother and sister. Not only that, but on the sire's side Panmure was not only sire but also grandsire. Yet Monarch was such a superior individual, and his breeding was so good, that he was bought by William McCombie and placed at the head of his herd. In his work on "Cattle and Cattle Breeders" that breeder writes, as evidence of the merit of Panmure's breeding, transmitted to his herd by his son, that "some of my best stock trace their descent from Panmure." The importance of this statement becomes apparent when we consider that McCombie stands in history as the most successful of Angus breeders.

Mr. McCombie purchased at Ardovie the cows Queen Mother and Jean Ann, that were full sisters, sired by Panmure and out of Queen of Ardovie (29). He bred Monarch (44)) to each of these, resulting in 1847 in the production of Lola Montes (208), and in 1849 of Bloomer (201), two famous prize-winnlng cows in their Gay and generation. This was in-andin-breeding with a vengeance. In 1852 Lola Montes was bred to Angus (45), a superior bull bred by Hugh Watson, and from that union she dropped a heifer named Charlotte (203), which became a prize winner at Paris in 1856. A bull named Hanton (228), that was the first prize Angus male at the Paris exposition the same year, and shown by McCombie, an animal tracing three times to Panmure, was bred to Charlotte. From that service in' 1857 she dropped the heifer Pride of Aberdeen (581), the foundress of the Pride family of the Queen tribe, whose "career is without a parallel in the chronicles of the breed." She was a most remarkable cow, creating a sensation at Sccich shows for three years, and making a great impression at the international show at Battersea in 1862 . The famous Prince Ito (12869), that in 1902 sold for $\$ 9,100$ in Chicago at public sale, the Angus record price, is five gen- 
erations descended from Pride of Aberdeen in a direct line on the dam's side.

One cannot trace a Queen Mother or Pride of to-day without running back into the blood of Panmure. A study of many an Angus pedigree will show that Panmure played his part, although often overlooked through the space of time. Yet the very best blood of the Angus cattle of Scotland secured from him a rich part of its inheritance. 


\section{YOUNG VISCOUNT (736) 181}

Young Viscount (736) was caived in 1873 , being bred by William Duff, Hillockhead, Glass, Scotland. His sire was the bull Hampton (492), while-his dam was Erica $3 d$ (1249) of the Ballindalloch Erica tribe. When a calf Young Viscount was purchased by the Earl of Fife at Duff house, near Banff, Scotiand. His superior character became manifest as a caif, and he was shown as a yearling at the Highland and Agricultural soclety show at Inverness, Scotiand, in 1874, where he won first prize in his class. The following year he was shown at Glasgow, where as a 2-year-old he gained first. Again, in 1876, at Aberdeen he competed in the aged bull class. and again received the coveted first place. In notes on the Highland show animals, in reference to Young Viscount, William Macdonald, editor of the North British Agriculturist, writes of him, in reference to the Inverness show, as "the highest-priced bull and perhaps the best-looking animal of the breed that has yet been shown." The following year at Glasgow he writes of him as "looking compact and shapely, though less striking than he afterward appeared." At the Aberdeen show Young Viscount seemed in better bloom, and Mr. Macdonald wrote that he "here looked almost perfect in form. Deep, square and level, he lacked length of neck a trifle, but he had no other fault, and was 'head and shoulders' above his compeers in the aged class."

In 1875 this bull won the $\$ 250$ Challenge cup, and in 1878 the McComble prize at the Royal Northern show of about $\$ 75$ for the best breeding Angus bull in Scotland. In order to make his claim good for being a grand individual he won first prize as aged bull and a special prize of about $\$ 150$ at the International Exposition at Kilburn, London, in 1879. These various records indicate 
great show character on the part of Young Viscount. It is a remarkable record for any bull to campaign for six years and have an unbroken list of first prizes. So great an impression as an individual did he make that in 1882 Campbell Macpherson Campbell wrote of him: "Young Viscount is an undefeated bull, and is acknowledged by breeders to be the best bull of the breed ever seen."

In 1878 this son of Erica $3 d$ was purchased by Sir George Macpherson Grant for 225 guineas (about \$1,125), the highest price paid for an Angus up to that time. From then he went into active breeding service in the Ballindalloch herd, where he was used with great success, as will appear further on.

Young Viscount possesses special interest for American breeders, as well as British. While retained until his death in Scotland, he proved to be a male of great prepotency, and his descendants have played a most important part in American Angus development. Reference to almost any catalogue of to-day, showing pedigrees of this breed, will show the name of Young Viscount occurring four to six generations back. Several of his sons are worth more than passing comment. No doubt his most distinguished son was Ermine Bearer 1749 , out of Erminia 1750. This bull was imported from Ballindalloch by Mossom Boyd \& Co. of Bobcaygeon, Canada. In their herd he proved a great sire, and his sons, Abactor and Abbotsford 2702 became two great bulls. The former sired Jean's Abactor 2d, the first prize yearling bull at the World's Columbian Exposition in 1893, while the latter, as the sire of Black Monk 13214, secures permanent place among the famous slres. Mr. McGavock, referring to Ermine Bearer in the Breeder's Gazette (Aug. 28, 1901), says: "Ermine Bearer is, I believe, entitled to the distinction of being America's foremost sire of high-class producing dams." Lucia Windsor, a daughter, was dam of Gay Lad 19538, the champion bull of 1895 and 1896, which as a 5-year-old sold at $\$ 3,050$. Another daughter, Lucia Estill, sold in the Estill dispersion sale at $\$ 2,800$. There are numerous descendants of Ermine Bearer that became great prize winners.

Another son of Young Viscount that attracts attention is Bushranger (2012). 
He was bred at Ballindalloch, and came Into the possession of Estill \& Elliott. where he was for some time at the head of the Woodland herd at Estlll, Mo. He was a very short-legged, thick-fleshed bull, and sold at public auction at $\$ 1,150$. He was the sire of a champlon bullock of the 1888 fat stock show named Dot, and of a bull named Estlll Erick, that proved to be a high-class sire of producing dams.

Still another son of Young Viscount was King of Trumps 2690, out of Duchess of, Verulam 2748, owned by Mossom Boyd \& Co. of Canada. Thls bull had the same great prepotency seen in his sire, and was also a celebrated show animal. In 1883 he was flrst prize 2-year-old at Toronto, and also at the Dominion exposition at Ottawa, winning a silver medal at the latter show as the best bull of any age. In 1884 he again won first prize at each of these falrs, and in 1886 was first prize bull at Toronto for the third time.

A daughter of Young Viscount, bred at Ballindalloch, by the name of Katinka 778 (4669), cost $\$ 1,500$ in Scotland, and was a cow "of wonderful individual merit." She was owned by Wallace Estill of Estil, Mo., and proved to be an excellent dam.

The great importance of Young Viscount's blood has been best seen in mating with the Blackblrd tribe. Take up a catalogue showing prominent Blackbird breeding, and Young Viscount and his descendants make a striking showing. Take, for example, the pedigree of Black Monarch of Emerson 30331, one of the prominent service bulls of to-day. He is six generations removed on each side of the family from the subject of this sketch, Young Hero 1921, his son, being sire of Rugby 6140. The latter, bred to Blackcap of Keillor Lodge 2095, dropped the famous Blackbird Hero 14494, the grandsire of Black Monarch of Emerson, on both sire and dam's side. The blood of Young Viscount, however, is found abundantly in other tribes.

Volume 1 of the American AberdeenAngus herd book contains 5,200 names of animals registered, and Young Vlscount was sire of thirty-two of these, twentythree being bulls. These sons of his are sires of hundreds of animals registered in this volume, many of which are vell known to fame. 
It is hardiy a third of a century ago that Young Viscount appeared as a candidate for show honors and breeding fame. His record in competition with the best in the Scotch show ring, and the added records of offspring and descendants during twenty-five years in Angus history, stamp him as the greatest breeding bull since 1875 . Many claim him to be the greatest Angus buli in history, and there are many facts to support their argument. 


\section{JILT (973) 422}

Among the various tribes of AberdeenAngus cattle the Jilt stands prominent. We naturally pay considerable deference to a matron of dignified and Impressive bearing and quality, but in the case of Jilt (973) 422 , the foundress of this tribe, there are quite exceptional reasons why one should pay her homage. She was not the greatest of show cows in her time; there were better ones. Yet she was a worthy individual, for she was a second-prize winner at the Highland and Agricultural show of Scotland in 1864, and won the same place the next year at the Royal Northern. In view of the fact that both McComble and others were making great shows of Angus in those days, a second place in the ring must mean much of individual merit.

Jilt (973) was bred by William McCombie at Tillyfour. She had for sire one of the most impressive and valuable bulls of that time, Black Prince of Tillyfour (366) 77, a descendant of Queen Mother, while her dam was Beauty or Tillyfour $2 d$ (1180) 423. The sire was bred by McCombie and the dam by Watson, and each animal represented the blood from which great individuals may be created. Jilt was dropped in 1863 , and in 1867 was purchased at McCombie's sale for about $\$ 350$ by Sir George Macpherson Grant for the herd at Ballindalloch. When she was 10 years old, Thomas Far. rall, in a prize essay on this breed, pub. lished by the Highland and Agricultural society, wrote: "Though several summers have somewhat dashed her bloom, she is still a cow of great size and many good points."

Although the Ballindalloch herd is a very old one, McCombie regarding it as one of the oldest in north Scotland, it has been sald that it got its first good start with the Jilt stock. And this leads us to Jilt, the breeder, and here she stands out In history as a really wonderful cow. So superior as individuals and breeders were her sons that she ha: been happily termed "the mother of monarchs," the appropriateness of which will appear farther on. Jilt bred to 16 years of age and had nine calves, and as she ceased to breed was slaughtered 
In her seventeenth year. The following is a list of Jilt's sons and daughters:

Juryman (404) $421 \ldots \ldots \ldots$..... Sire, Brlght (454) 375 Jester $(472) 1471 \ldots \ldots \ldots \ldots \ldots \ldots \ldots \ldots \ldots . . . \ldots \ldots$

........ Sire, vietor of Ballindalioch (403) $52 \mathrm{~S}$ Jewel (1413) $1669 \ldots \ldots \ldots \ldots \ldots \ldots \ldots \ldots$.

........ Sire, Victor of Ballitudalloch (403) 528 Jewess (1916) 852. ...... S1re. Exciseman (473) 801 Judge (1150). 473........... Sire, Scotsman (474) 482 Judy (2996) $\$ 131 . \ldots . . .$. . Sire. Bailimore (7t1) 474 Juno of Ballindalloch $(3374) \cdot 1900 \ldots \ldots \ldots \ldots$. ...................... Bire, Ballimore (74i) 474 Justice (1462) 854 ............ Sire, Elcho (595) 527 General of Tillyfour (1332) 5158............... .................. Pire. President 4 th $(36 \dot{8}) 279$ - These are all recorded in volume 1 of the American Aberdeen-Angus Herdbook, as the registration numbers show. Besldes these, according to Judge GoodWin, there is another son, named Jacke: sired by Edițor, but not registered in the American book.

It is interesting to note here that custom occaslonally adopted by the breeders of naming stock with a uniform lettera method apparently well perpetuated in the Jllt tribe, and, as Farrall says, "a race or famlly of J's difficult to compete with."

It will be well to briefly consider some of these sons and daughters of Jilt. Juryman, Judge and Justice, brought everlasting fame to the memory of the cow. They formed a great trio, and Americans must be especlally interested in them from the fact that both Judge and Justice were purchased and used by Judge J. S. Goodwin (then of Beloit, Kan.) in his herd.

Juryman made his first appearance in the show rlng at the Highland at Dumfries, winnlng first place, and again at the 1871 Hlghland at Perth, winning first as aged bull. In 1871 he was referred to as "a remarkably good looking as well as a most valuable stock bull."

Judge was calved in 1875, and he secured fame by winning first prize in the aged bull class at the Parls exposition, and so has been dubbed "the "world beater." "He was imported to Rougamont, Quebec, by George Whitfield, who later sold him to Judge Goodwin, in whose possession he died.

Justice, "the incomparable," was calved in 1878, and he, perhaps, attained the most fame of these famous "brothers. Justice was first shown as a yearling at Perth in 1879, and at the Highland show, where he was "splendldly brought out," and won first place in class. In 1880 , at the Highland at Kelso, he was second as 
2-year-old, "through a little lightness around the girth," being defeated by Prince of the Realm. The next year, however, at the Stirling Highland show, with the same two bulls in the ring, this decision was reversed, and Justice became the first prize aged bull, the highest Angus honor in Scotland. The quality of Justice was said to be quite remarkable. It is Interesting to note, regarding him, that he was sired by a half brother, his grandsire belng Juryman, Jilt's first calf, out of the original Erica (843). Here we have a union of two of the greatest Angus tribes of cattle. from which most fortunate results were secured. Judge Goodwin made a special trip to Scotland and purchased Justlce, and he died at Beloit, In his herd, on July 3, 1886.

Jewel has been considered the best daughter of Jilt. She was shown at the United Banffshire show, where she won first prize and a cup as the best polled animal exhlbited, but she fell, to third place at both Highland and Royal Northern shows in 1877. She proved to be a high-class breeder, and was first as one of a pair of Angus breeding corvs at the Royal Northern in 1878. Her son, Jupiter of Aberlour, was a famous prize winner, and a daughter, Jill, was about the first close descendant of Jilt to be imported to America.

Jewess was a very large cow of an excellent sort that was retained to breed at Ballindalloch.

Mainly through the preceding five sons and daughters has come most of the fame of Jilt. The bulls were used extensively at Ballindalloch, and with considerable success; in fact, with greater success than marked the career of Judge and Justice in America. The Jilts have proved to be great bull breeders, and consequently much of the reputation of the tribe has come from this source. Referring to this feature, Judge Goodwin, in an interesting communication on Jilt in the Breeder's Gazette (June 22, 1892) says: "For a number of years there was scarcely any female increase at Ballin. dalloch, and as a result almost the entire reputation of the family has been made by the bulls. Those sold from the herd, however, have been very prolific, until now more Jilts are owned away from Ballindalloch than there, although only four females have been disposed of in the past twenty years, until within the 
past year. * * * It is on account of the facts just stated that it has been well nigh impossible "to'secure any of the females of this family at any price."

As before noted, Jilt was a cow of large size, and this quality in her seems to have been transmitted to her descendants, probabiy largely through her three great sons, for Judge Goodwin credits Judge witin weighing about 2800 pounds, and Justice exceeding 3000 pounds, each of which represent enormously heavy animals. The quality of flesh and softness of hair are also commented on as distinguishing features of the Jilts.

The blood of Jilt has been liberally used among the Ericas and Prides, and is found playing an important part in the best Prides of to-day. The sire of Prince Ito's dam is Justice, while Juryman occurs three times in the sixth generation on the sire's side. Young Viscount was bred with success to both of Jilt's daughters, Jewel and Jewess, and from those unions have come other J's, to the advantage of the breed.

Jilt in her three choicest sons was a thrice worthy matron, yet even Justice alone made impression enough on the breed to bring fame to such a dam. The excellence of Jilt should be indelibly chronicled in the annals of Scotch Angus history. 


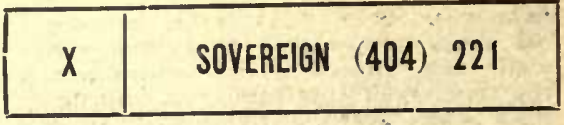

Early Hereford cattle history gives only limited information concerning those animals that had an important influence on the breed. The Tomkins family in Herefordshire is generally recognized to be the most important factor in the eariy improvement of the breed. This began with Richard Tomkins, who died in 1723; was continued by his son Ben Tomkins, known as the elder, born in 1714 and died in 1789, and concluded with Ben Tomkins, the younger, the greatest breeder of the three, son of the first Ben, born in 1745 and ded in 1814. Tomkins the younger had two bulls-Wellington (4) and Silver Bull (41). These are, so far as we know, the real great early improvers of the breed, yet we know comparatively little of their life history.

Following soon after the time of the two bulis named came Sovereign (404). He was calved at Purslow, Shropshire, in 1820, and was bred by John Hewer. Following Tomkins, no family had a more important influence in the development of the Hereford than that of Hewer. William was the father and John, the son, the breeder of Sovereign, was born in 1787 and died in 1873 . The importance of these two persons is indicated by MacDonald and Sinclair in their history of Heretord cattle, in which they state that "the student of the Herd Book will find that nearly every valuable strain of Herefords at the present day is full of Hewer blood."

Sovereign, also known as Old Sovereign, was sired by Favorite (442) and was out of a cow named Countess. Both his sire and dam were from the same parents-viz., Young Wellington (505) and Cherry, by Weliington (507). Consequently Sovereign was the result of the union of own brother and sister, the very closest of in-breeding known.

Just what the personal characteristics of Soverelgn were we can only confecture in part, for little description is left of him. In those days Herefords were varlable in color, and so late as 1846, when volume 1 of the English Hereford Herd Book appeared, the breed as based on color was placed in four groups 
-viz., mottle face, white face, gray and llght gray. Sovereign was typical of the modern Hereford in color, being white of face, breast, belly, top of neck, shanks and pasterns, and white brush to tail. The best judges of those days, It is said, found much of merit in this bull, and he was hired out to the following distinguished breeders during the fifteen years of his life:

Robert Tench, Bromfleld, Salop.

Lord Sherborne, Gloucestershire.

Farl Ducie, Gloucestershlre.

Thomas Wells. Hamnet.

Rlchard Klimister, The Grove.

Messrs. Hewer, Northleach.

Sir H. Hoskyns, Bart., Harewond.

Thomas Jefrrles, The Grove.

Thomas Jefries. Jr., Cotmore.

Edmund Jeffries. The Grove.

Rlehard Yeomans, Howton.

John Turner. Noke.

Messrs. Rogers, Sternsbach.

The influence of Sovereign on the herds owned by the breeders listed was simply remarkable, and he did more to spread abroad the fame of Hereford cattle than any other animal in his time. So prepotent was he, and so successful was Hewer, that many of the best Hereford breeders of those days were induced to introduce Hewer bulls into their herds. "Soverelgn is said to have done wonders in every herd he was used in," and the mating of his blood with that from Lottery (410) is sald to have been still more effective. Two men received very marked benefits from using Soverelgn in their herds-viz., Thomas Jeffries and Sir Hungerford Hoskyns. They were both famous breeders. The latter did much to extend and improve the breed, and during his time used fourteen different Hewer-bred bulls.

Probably the most distinguished animal sired by Sovereign was Cotmore (376) 150 , which he sired when 15 years old. He was bred by Thomas Jeffries and was the first-prize Hereford male at the initial show of the Royal Agricultural soclety held at Oxford in 1839. It is given in Hereford literature that Cotmore weighed thirty-five hundredweight, or 3920 pounds, so that he was an animal of most unusual size, while his sire was not. Soverelgn also sired Wormelow, an animal of much merit, owned by Sir H. Hoskyns, "and many others of equal merit." Among his helfers was Fatrumps, the first-prize cow of 1840 at the Royal show. Spot, the winning cow at the 1839 Royal, was by a soll of Soverelgn. 
In consideration of the fact that this bull lived to be 15 years of age, and was used in at least fourteen different and prominent herds, it is almost impossible to see how one could trace back the peaigree of Hereford cattle to early days without getting into Sovereign blood. Sir. David, known as one of the great Hereford bulls of history, was a greatgrandson of Sovereign, and probably derived some of his excellence from him. The blood of Grove the 3d, famous both in England and America, runs back through Sir Benjamin to Sovereign. The same may be said of Garfleld, Earl of Shadeland 22d, Eiton 1st, Lord Wilton and a host of others.

The profits derived from the use of Sovereign were very unusual. Not only was there that unmeasurable value from having such a sire in the herd, which Hewer enjoyed, but it is also said that Hewer recelved $£ 64018 \mathrm{~s}$, or about $\$ 3,205$, from the various people who hired the bull. The fact that Sovereign was used by so many people is an expression of good will on the part of Hewer toward. his-fellow-breeders, which is a happy. condition for us to look to, even in this day and generation. Sovereign certainly was worthy of his hire. 


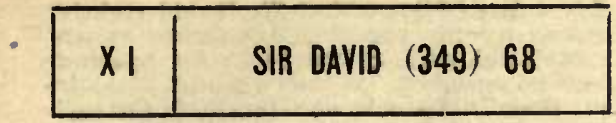

Just about a quarter of a century after the birth of Sovereign another epoch-making Hereford sire appeared on the scene. Sir David (349) 68 was calved Feb. 13, 1845, and was bred by David Williams of Brecon, Wales. Brecon is a town of nearly 6,000 inhabitants, lying about thirty-eight miles westerly from the city of Hereford.

Sir David is entitled to a place in the Hereford list of old worthies for two distinct and different reason-first, he was a great show bull in his time, and, second, he proved himself to be one of those breeders which only rarely occur in the history of a breed. His show yard career really began in 1846, when as a yearling at the show of the Royal Agricultural society he won the first prize in class of twenty sovereigns at Newcastle-on-Tyne. He was then shown by J. N. Carpenter of Eardisland near. Leominster. At the Royal show in $\mathbf{1 8 4 9}$ at Norwich he was shown by Edward Price, Court House, Pembridge, when he won first place in the aged bull class. He also won the challenge sweepstakes at the Royal shows of both 1848 and 1849 . At the Hereford Agricultural show in 1848 he was first prize in class, and the following year at the same show was first with cow and offspring. Both in 1848 and 1849 he won first prize and sweepstakes at Hereford in competition open to ail England. Again, in 1848, he was first at both Ludlow and Leominster with four of his offspring.

Such a record as this in the show ring, in the very heart of the Hereford country, must clearly pojint to a bull and sire of extraordinary merit.

The ancestry of Sir David is a matter of uncertainty. His sire was Chance (348), and his dam, Duchess, was mated to her own sire, which was also Chance, from which came Sir David. Back of Chance lies the uncertainty; his dam was a cow named Victoria, which got loose and into a field with several young bulls, on which occasion she got in calf. As some of these young bulls were by her own sire it will be noted that Sir David is strongly in-and-in bred. The dam of the cow, Victoria, was sired by 
Sovereign (404), so that Sir David rightly comnes by his superior excellence as an individual and a breeder. As bearing on his pedigree, Macdonald and Sinclair in their "History of Hereford Cattle" say: "Iord Berwick's sale catalogue of Sept. 23, 1858, extends his pedigree, stating, in notes to lots 34 and 102 , that he was the son of Duchess, and this is corroborated in a note to lot 1 in the Cronkhill sale catalogue of Sept. 17, 1861, when the herd was dispersed after Lord Berwick's death. If this extension is correct the pedigree of Sir David should stand thus: Sire, Chance (348); dam, Duchess by Chance; grandam, Old Duchess by White Nob (345); greatgrandam by Young Wellington (505)."

The real significance of the importance of Sir David in Hereford history is to be seen in the character of his offspring and his descendants. One of his most prepotent sons was Sir Benjamin (1387), an animal that became famous in the show ring as well as a breeder. Sir Benjamin was sire of Sir Richard, a bull that was second at the Royal show in 1858 at Chester and first at the Leed's Royal in 1861. He also was a prize winner at Hereford, Ludlow and Leominster. Sir Benjamin was an illustration of the value of crossing blood lines that would nick well together, fo: he was the result of a union of Sir David with Mr. Rogers' Prettymaid family. Sir David was 11 years of age when Sir Benjamin was calved.

An important granddaughter of Sir David sired by Sir Benjamin was Queen of Lilies (1387). She won the first prize $a$ : the Royal show at Manchester in 1869 , and she was also a winner at the Bath and West of England show at Southampton. She was bought by the Earl of Southesk and was later purchased by Philip Turner of the Leen, in whose hands she became a great breeding cow.

Pembridge (721) was another famous son of this bull, and he is described as being "a larger and grander bull than Sir Benjamin; of great constitution and very level all over; in color very dark, with a beautifully soft and abundant coat of long. wavy hair and little white." He was winning calf at the Royal show at Norwich in 1849, and was first in class at the Royal in 1852 at Leeds, while he was a winner at both Ludiow and Hereford. Referring to Pembridge, William Housman says that he aiso inherited Sir David's marvelous impressive power. 
Stanway (2790), bred by William Tudge, and the first-prize aged Hereford bull at the Royal at Oxford in 1870, was a great-grandson of Sir David. In fact, as one glances along down the line of great show winners in England between 1850 and 1870 , he must be impressed. with the great part the blood of Sir David plays in the pedigrees of these animals. Here one finds sons and daughters, grandsons and granddaughters, and still others, winning the cholcest places in Hereford competition.

Back to Sir David do we trace some of the choicest blood lines of American Hereford stock. Corrector and Improver, two of T. F. B. Sotham's great bulls, trace back on both sire and dam's side to Sir David. The Grove 3d 2490, Earl of Shadeland 22d 27147. Garfield 7015, Sir Richard 2d 970a, Cassio 11353 and a host of others descend in various degrees from Sir David.

British authors that discuss the Hereford breed pay high tribute to this bull. William Housman, one of the very best authorities on the beef breeds in England, in his excellent work on "Cattle, Their Breeds and Management," referring to this bull, says: "The influence of Sir David as a sire proved to be one of those extraordinary powers which in the histories of breeds occasionaliy rise up far beyond the expectations of the breeders from whose herds they come forth." He further says: "It is not possible here to enumerate the illustrious descendants of Sir David: the prize lists of the leading agricultural societies are full of them." Macdonald and Sinclair, in their work on "The History of Hereford Cattle," class Sir David as "one of the most influential sires known in the history of the Hereford or of any other breed of cattle."

This bull was used in eight different herds, but he was most intimately identified perhaps with those of Edward Price, Court House, Pembridge, and Lord Berwick, at Cronkhill. He passed his latter days in Lord Berwick's herd, where he sired a number of animals of merit, including Conqueror (1929). At 15 years of age he was sold to a butchera most miserable and degraded ending for a bull that had contributed so much during a long lifetime to the uplifting of a breed. Certainly he was entitled to a more generous treatment in the sunset of life. 
American literature contains but scant reference to Sir David. Yet many of the comments on the Hereford breed pay tribute to him through the laudation which comes to his descendants. Yet a half century is a long time in the history of a breed, and animals of emtnence to-day in the space of time become rapidly forgotten. The student of Hereford pedigree, however, that carries his work back to foundation stock will readily comprehend the importance of Sir David in this connection. 


\section{LORD WILTON (4740) 4057}

It is an interesting coincidence that some of the most famous of Hereford cattle bred in England were favored with titled names. Soverelgn, Str David and now Lord Wilton (4740) 4057, were all of the highest character in thelr generation. The latter individual, however, was the sensational bull of his day, and in all that goes to make a great bull he perhaps may be regarded as the greatest Hereford sire in history. His story runs after this manner:

Lord Wilton was bred by William Tudge of Adforton, England, and was calved Aug. 30, 1873. His sire was Sir Roger (4133) 3850, and his dam was Lady Claire by Marmton (3242) 4117. On the side of the sire Lord Wilton traces back to Sir Davld through Sir Roger, Sir Thomas and Sir Benfamin. On the dam's stde, second dám Lady Adforton, by Pilot (2156), third dam Lady Ashford, by Carbonel (1525), fourth dam Lady, by. Orieton (901), fifth dam Lady, by Nelson (1021), sixth dam Lady, by Turpin (300), seventh dam Lady, by Tully bull. On both stre and dam side Sir David is no unimportant factor in Lord Wilton's pedigree.

In Mr. Tudge's hands Lord Wilton as a calf won first in class in 1874 at the shows at Leominster and Ludiow, though his half brother, Regulator (4898), won over him at the Royal show at Bedford, and at the Bath and West of England at Bristol, and the Hereford Agricultural at Hereford in 1874. In 1875 , as a yearling, with Regulator out of the contest, Lord Wilton won first place in class at the Royal Agricultural Soclety of England show at Taunton, at the Bath and West of England show at Croydon, and the Hereford Agricultural society show at Hereford. He had, however, been purchased at the Croydon show by Lewis Lloyd of Monk's Orchard, Surrey, and from Hereford he went to his new home. Here he stred some superior stock, and especially steers, that were shown at Smithfield, but the herd was not in the Hereford district, and little attention was directed to him. In $1879 \mathrm{Mr}$. Lloyd exhibited Lord Wilton at the Kllburn In- 
ternational show, but he was not in the best form, and could only get the place of "commended." Here T. J. Carwardine of Sţocktonbury, Leominster, was attracted to $\mathrm{hlm}$, and after negotiating with Mr. Lloyd exchanged him for a bull calf and $£ 5$ (\$25). In 1881, in Mr. Carwardine's possession, Lord Wilton won first and championship against all breeds at Lord 'Tredegar's show at Newport, and again at the same show in 1882, defeating this latter year Mr. Rogers' Archibald (6290). At Leominster in 1882 he was in the bull, cow and offspring class, and helped secure the first place, while this same year he was the first prize bull at the Shropshire and West Midland show at Ludlow. This closed his show yard career.

Writing of Lord Wilton's personal characteristics, William Housman has thus expressed himself: "Lord Wilton does not fill the eye as an absolutely big bull, but he has ample proportionate length, and, like the Adforton bulls in general, a robust character, the bone not too heavy, but made to bear a great weight of beef, and. he furnishes heavily in the fore flank and other flesh points. His head has plenty of width across the upper part, not too much length in the lower part. The horns of medium size for a Hereford, and of inward and descending curve, harmonize with the kind$1 y$, open countenance, and the hanging lap of surplus skin glves masculine depth from ear to throat."

Further evidence as to the charadter of this bull is quoted from an uninamed English paper in Shadeland Farm catalogue, as follows: "At 10 years old he carries a magnificent form and appearance, belng very massive, broad and deep, standing low to ground, with great solidity and substance; but remarkably even, and no coarseness whatever. One striking feature is his full, deep chest and great girth behind the shoulders, with fullness at crops, chines and loins."

The death of Mr. Carwardine resulted In it being necessary to sell his herd, so that it was put up at public auction by Alfred Edwards on Aug. 28 and 29, 1884. This was the great sale in Hereford history, and Lord Wilton was 1ts stellar attraction. In the Christmas number of the Breeder's Gazette for 1900 John Hill, who interestingly writes "The. Story of Lord Wilton," gives the following account of his placing under the hammer: 
"The sale at Stocktonbury brought together a very large company, and speculation ran high as to what the animals would realize. Prices exceeded even what was expected, and when the great bull came into the ring the excitement was intense. The two last bidders were Slr James Rankin, M. P., and Mr. Vaughan. When the sum of 3,000 guineas was reached there was a pause. Sir James unfortunately had to leave before the bull was offered, or the result would probably have been different. He left his bailiff, Mr. Shaw, with instructions to secure Lord Wilton, and, sitting close to Mr. Shaw and just above where Mr. Vaughan was standing, I heard the former bid 3,700 guineas; then the latter capped it with an offer of $3,800(\$ 19,000)$. Mr. Shaw, in the absence of his employer, prudently retired from the contest and the hammer fell. A most regrettable incident afterward occurred, the purchaser failing to find the amount due. It ended in a further auction the following spring, and Lord Wilton became the joint property of Messrs. W11liam Tudge of Leinthall and Thomas Fenn of Downton, at 1,000 guineas $(\$ 5,000)$."

The success of Lord Wilton's offspring in the show ring first attracted attention in 1881, when the bulls Sir Bartle Frere (6682) 6419 and Romeo and the heifers Venus and Henrietta were first in their classes at the Royal Agricultural society of England show at Derby. Mr. Carwardine brought his herd prominently before the public at the important shows, "and its constant successes became the chief subject of conversation in the Hereford world, both at home and abroad."

Many of Lord Wilton's sons and daughters have attalned fame in both show ring and the breeding herd. Sir Bartle Frere was purchased by Adams Earl for his famous Shadeland herd at Lafayette, Ind., he paying $\$ 3,000$ for him. $\mathrm{He}$ won the most distinguished honors in the leading English and American shows, as well as siring many. great sons and daughters, both for Mr. Carwardine and Mr. Earl. He died in service at Shadeland in his seventeenth year, a great son of a great sire. Sir Bartle Frere, Monarch, Hotspur and Grove Wilton 3d-all sons of Lord Wiltonwere all first-prize winners at the Royal show in England, as were also his daughters Venus, Henrietta and Dorothea. 
The offspring of the above sons and daughters also took prominent place at the Royal and other shows. Monarch had three sons that were Royal winners, while another son of Lord Wilton, named Baugham, had two sons and two daughters that were Royal prize winners. Other sons of Lord Wilton that had prize-winning offspring at the Royal on different years unite to make a most remarkable showlng for this bull. It is a record that perhaps cannot be equaled in British cattle history.

Lord Wilton died in May, 1886, of heart disease whlle still owned by Messrs. Tudge and Fenn. While the loss was great, he left in their possession some very choice stock, which materially assisted in maintaining the reputation of these well-known herds. Lord Wilton blood has been extensively distributed over America through his transported sons and daughters and their descendants. much to the adyantage of our herds. To him American Hereford breeders are indebted for much that is best in their herds. 


\section{CHAMPION OF ENGLAND (17526)}

Up in north Scotland, in a land of rugged worth, developed Scutland's greatest Shorthorn breeder, Amos Cruickshank. Taking up his work along in the latter years of the days of Thomas Bates, he sought to develop a class of Shorthorns of pronounced constitutional vigor, thick fleshed, early maturing and compact of form. Patient, quiet, determined, he held to his task and sought to create his ideals. Finally, after more than a score of years, came a bull calf into his hands that furnished the long lacking medium of Improvement.

Champion of England (17526) was dropped on Nov. 29, 1859. He was a roan in color and had for a sire Lancaster Comet (11663), while he was out of Virtue by Plantagenet (11906). Lancaster Comet was used in the herd of Mr. Wilkinson, and he was a grandson of Will Honeycomb (5660) on both sire and dam's side, a thick-fleshed, level-backed, deepbodied, short-legged bull of much quality. Lancaster Comet had a coarse horn and head and was not much admired by Cruickshank until his real worth as a breeder became demonstrated. Verdant, by The Exchequer (9721), the dam of Virtue, was a thick-fleshed cow of real merit, bred by Cruickshank. She had twin heifers, Virtue and Verdure, by Plantagenet, and they both proved great breeders. Verdure was the dam of Scarlet Velvet (16916), "a bull of much value in the herd of Campbell of Kinellar. Virtue, the dam of Champion of England, is said to have been a red cow with some white, rather given to excessive milk production when suckllng a calf, and fleshing readily when dry. The ancestry of Champion of England - shows that he was entitled to inherit the valued qualities of the beef-producing Shorthorn.

As a calf Champion of England did not excite large expectations. He was

$$
-47 \text { - }
$$


exhibited in 1861 at the Royal Agricultural society of England show at Leeds, but did not secure a place. This was due to the fact that he was in the yearling class and had to compete against 2-year-olds. At Aberdeen, Scotland, he succeeded in winning third place. The fact was, Champion of England was not an outstanding show animal, and this fact for a time led Cruickshank to consider selling him. Yet his owner finally decided that he was worth a trial, for he had plenty of quality and thriftiness. Robert Bruce, writing of him only two years ago in the Breeder's Gazette, said: "It has often been to me a matter of regret that I did not look at this bull more carefully when I saw him at Sittyton. At that time I was deeply smitten by the then fashionable 'pedigree belief,' and such a bull as Champion of England, an animal having no show yard record, failed to interest me much. He was passed over with the note: 'Good animal; great covering of flesh; underline not so good; quarters wanting finish.' The thickness and substance of his thighs appeared to me then to be less desirable than the flat, wide thigh common to the English Shorthorns."

In an article on "Recollections of Sittyton Cattle," also in the Breeder's Gazette, by A. Chalmers, who was personally familiar with Cruickshank's herd, writing of Champion of England, he said: "Champion of England was a production different from the original stock at Sittyton, and his formidable appearance was that of strength and constitution-more bone and less style, heavy head, thick, smooth chine, stiff loin, hook bones slightly down from line of back, smooth, well-filled rumps, with square hindquarter and heavy twist." It may also be said additional to the above that he was extremely strong in his foreribs and showed in his development great feeding capaclty. His droopIng hindquarters he very likely inherited from his dam, "a good-sized red animal with plainish hindquarters," says Mr. Jamieson.

Champion of England not being a strong candidate for the show ring, his reputation must thus be due to his merit as a breeder. And here lay his preeminent merit. It was soon seen that he was getting calves of the broadchested, full-ribbed, thick-fleshed. shortlegged class. As used in the Sittyton 
herd. says Chalmers, he gave Cruickshank's Shorthorns "more strength of frame, with less inclination to width of hook bone, increased the weight of muscles and gave it on essential points, and the calves were sturdy at. birth. In the combination of strength of frame, welght, quality and constitution all were banded together with no little beauty."

The use of Champion of England began in the Cruickshank herd in 1860. Prior to that time bulls of various breeding had been used in the herd. With Champion of England, however, was introduced along with the use of other bulls the practice of in-breeding. The best of results did not follow this practice all the time at Sittyton, but with Champion of England and his offspring highly satisfactory results ensued. As this great Scotchman continued $h$ is career he was instrumental in producing a number of great females that became improvers of the most popular tribes of to-day. In this work Champion of England was most important. Bred to Mistletoe by Lord Raglan (13244), he sired Mimulus, a great breeding cow, the dam of Royal Duke of Gloster (29864), a very successful breeding bull. His sire, Grand Duke of Gloster (26288), by Cnampion of Eng. land, although he died as a 2-year-oid, was regarded as perhaps his best son. Princess Royal, a magnificent daughtel of Champion of England, bred to Royal Duke of Gloster, produced Roan Gauntlet (35284), regarded as one of the greatest if not the greatest bull bred by Cruickshank, excepting the subject of this sketch. Roan Gauntlet was sire of the famous Field Marshall (47870), the sire of the great cow Princess Alice, Imported to America by Colonel W. A. Harris. She was dam of Royal Hero 113611, the champlon Shorthorn bull in America in 1899, in the ownership of W. T. Miller, Carlos City, Ind. She was also dam of Young Marshall 110705 and Royal Knight 117203, both high-class bulls.

Among the famous cows sired by Champion of England, besides those mentioned, are Village Belle, Village Rose, Morning Star, British Queen, Carmine Rose, Silvery, Surmise, Circassia, Violante, Finella and Victorine. The value of this bull to Cruickshank consisted in the unusual merit of these cows as indlviduals and breeders. Not oniy this, but his sons and grandsons proved such prepotent transmitters, such su- 
perior individuals, that they produced large results in the Scotch herds in which they were used. They were found to nick advantageously in those Scotch tribes that lacked rib and heavy fleshing. qualities.

Champion of England will live in hiss tory as the greatest and most potent Shorthorn sire of Scotch breeding. It would be impossible to measure his influence on the breed of to-day, but sufflce it to say that his sons and daughters and their descendants make up a long list of the famous breeding and prizewinning Shorthorn cattle of America as well as Great Britaln. His history and his influence merit careful study on the part of all Shorthorn students. 


\section{YOUNG MARY}

In 1833 there was organized at Chlllicothe, Ohio, what was known as the Ohio Breeding and Importing company. This was a stock company of prominent stockmen, with the real purpose In view of importing Shorthorn cattle to America. In January, 1834, Felix Renick salled to England, where, as agent of the company, he purchased seven Shorthorn bulls and twelve cows. Among these were two yearling heifers-Young Phyllis by Fairfax (1023) and Young Mary by Jupiter and out of Mary by Saladin (1417) -that later became the founders of two of the most popular and valuable Shorthorn families in America. The former was bred by the Earle of Carlisle and was of very superior breeding, while the latter, the subject of this sketch, was bred by J. Clark, a slightly known breeder, and dld not have a pedigree of importance compared with the other cows imported. In England Young Mary cost $£ 2610$ s (about, $\$ 130$ ).

These two heifers were taken to Ohio in 1834 and placed upon the farm of Felix Renick in Ross county. Here Young Mary was kept for about two years, when she was sold at an auction sale held by the Ohio company on Felix Renick's Indlan Creek farm, on Oct. 29, 1836. This sale is of special interest from the fact that it was the first company Shorthorn sale held in Amerlca. Young Mary, then a 4-year-old, had a

heifer calf at foot named Pocahontas, by Comet Halley, and the pair were purchased by Edwin J. Harness of Ross county for $\$ 1,500$. That same season Messrs. Vanmeter and Cunningham took an interest in the cow and calf with $\mathrm{Mr}$. Harness, and by mutual agreement took her to Kentucky. where she passed the remainder of her life on the farm of Mr. Cunningham. Mr. Harness dled soon after the sale, so the heifer was then owned by the other two partners.

Young Mary had no show yard career, neither was she a distinctly show animal. Sanders says she is descrioed as having been a large cow of striking appearance, a light roan in color, with some white, especially on her legs. Her horns, which were inclined to be "crum- 
pled," were rather strong and well carried out from her head, which was broad and well shaped, with a good full eye. Her neck was rather thin, shoulders smooth, back broad, rib deep, udder large and good. She was characterlzed as being a remarkable milker and one of the best milking Shorthorns owned in the Vanmeter herds. During the early stages of lactation, if on grass, she produced "a large pailful of milk morning and evening after the calf had drunk its fill."

Young Mary proved to be a very long lived and prolfflc cow. While authorlties do not entirely agree, she at least lived to be 21 years old, having a heifer calf then, which soon died. B. F. Vanmeter, a grandson of Captain Cunningham, gave her produce as sixteen helfers and four bulls. Her first calf was a roan bull named Davy Crockett, calved on Dec. 5, 1834, and sired by a bull Clark. Her second calf, another roan bull. named Logan, was sired by Duke of York (1941), and was dropped Oct. 27, 1835. These two bulls were sold in the same sale Young Mary was in, and Davy Crockett was purchased at $\$ 490$ by Peter L. Ayres of Ohio and Logan by Jonathan Renick of Pickaway county, Ohio, at \$750. Ayres was a man who did not keep up his pedigrees, and no record is left of the influence of Davy Crockett. Pocahontas, the third calf of Young Mary, was dropped in 1836, and was sired by Comet Halley (1855). Her fourth calf was a red and white bull named Romulus by Matchem (2283), that was bred in Kentucky and was bought by James Stonestreet of Clark county, who used him in but a small way on pure-bred stock. Besides the above, by the bull Goldfinder (2066) she produced five calves -viz., Hannah Moore, Judith Clark, Lllac, Florida and Sarah Hopkins-that developed into high-class, valuable cows. Hannah Moore was a very successful show cow, was well known on the Kentucky fair grounds and is said to have been undefeated. In 1886 William Warfield, than whom there is no greatel authority, wrote: "There never has been a time since 1836 when Young Marys and Young Phyllises were not winners in the show rings of Kentucky, and apparently there wlll never be such a time."

Sanders in hls history of Shorthorn cattle states that Young Mary produced 
four bull calves, including besides the above a roan bull, Tom Bigbee by Prince Albert 2d, calved in 1848, that proved a show bull. The records, however, would make it appear that she had a fifth bull calf, for Bulmer, Jr. 302, by Bulmer 300 , on page 109 of volume 2 of the Shorthorn herd book, is given as a son of Young Mary by Jupiter. This statement, however, William Warfield informs me, is not true, and should have been corrected years ago in the herd book. When the Isaac Cunningham herd was auctloned off in 1855 nineteen head of "thoroughbred Durham cows" catalogued with one exception were Young Marys. Of these two were from Pocahontas, ten from Hannah Moore, four from Judith Clark and two from Lllac-all daughters of Young Mary. At Solomon Vanmeter's sale in 1859, when thirty-seven females were sold, nineteen were Young Marys.

Hannah Moore and Pocahontas were the most useful daughters of Young Mary. The former was foundress of the Beck Taylor, Leslle and Flat Creek branches of the family, and the latter of the Red Rose. Judith Clark, one of the other daughters, was a valuable breeder, the Grace Youngs and Leopardess strains descending from her.

The great breeding value of the blowd of Young Mary became manlfest at once in the mating of John Randolph 603, a son of Young Phyllis (lmp.) to Hannah Moore, from which came Queen Anne that was later the dam of Albert Gallatin 202, by Prince Albert 2d 857.

A daughter of Hannah Moore named beck was mated with much success to to a show Young Phyllis bull, Dlck Taylor, resulting in a red heifer that was named Beck Taylor. She was foundress of a popular branch of the Young Mary tribe. From Pocahontas was descended two remarkable Red Rose cows, owned by Ben F. Vanmeter, Red Rose 8 th and 11th. These became famous show cows in some of the greatest shows in Kenticky. Red Rose 8 th was champion Shorthorn cow at the Philadelphia centennlal. Her sister was also a prize cow at the same show. Later the Grooms of Kentucky bought and exported Red Rose 8th to England, where she was sold for $\$ 1,750$, while Red Rose 11 th was purchased by Mr. Fox of the same country at $\$ 2,325$. A son of Red Rose 11 th was. champion 4-year-old steer at the first American fat stock show held at Chlcago.

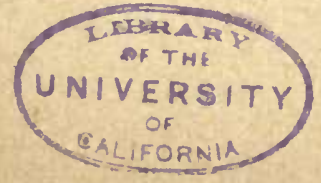


Young Mary breeding, met with very great favor in the middle west along in the 70 s. C. M. Thomas, writing of Kentucky Shorthorns In' the Breeder's Gazette (Aug. 1, 1900), says: "Not one but several chapters would be required to tell of the glorious achlevements of Young Mary and her produce." The Shorthorn catalogues of those days were loud in their praise of the blood of this family. One catalogue says: "Her descendants are counted by the score in almost every state where Shorthorns are bred. They have won lasting honors in "many well contested show rings all over the land and for useful qualities they have few equals."

The fame of Young Mary blood was world-wide, and as'late as 1887 a writer in the London Live Stock Journal writes: "Most of the Shorthorns bred in America are of tribes which had won great distinction here before the frrst of it 'crossed the water.' Still there are exceptions; and the Young Marys, one of the greatest families in the states, harl no reputation to speak of when the first was taken out."

Since the setting in of the Scotch Shorthorn tide the Young Mary family has not attracted so much attention from the younger breeders; neither is 1ts history so well known by the present generation. However, Young Mary, as 1ts foundress, may justly be regarded as one of the most distinguished and vaiuable of the pioneer. Shorthorn dams of America. 


\section{BLACK KNIGHT 4751}

Among the really great Aberdeen-Angus herds of cattie that have been in existence in the United States was that of T. W. Harvey of Chicago at Turlington, Neb. The development of this herd began along in the early ' 80 s, and William Watson, familiariy known as "Uncie Wil-' lie," a son of the famous Hugh Watson of Keillor, Scotland, was herd manager during the most interesting part of its history.

Black Knight 4751 (5887) was bred by Gudgell \& Simpson of Independence, Mo., and was calved on Oct. 30,1883 . His sire was Knight of St. Patrick (2194) 354, and his dam Blackcap (4C42) 1552.

The importance of this parentage of Black Knight is first worthy of consideration. His sire, Knight of St. Patrick, was a great show bull in Scotland and America. He was bred by R. C. Auid, Bridgend, Scotiand, and in 1881 won the Highland and Agricultural society sllver medal as the best bull at the LeochelCushnie Agricultural soclety show in Scotland. Soon after, in 1882, he was imported to America by Gudgell \& Simpson of Independence, Mo. Thereafter his merit as a show buil became manifest. In 1882 he was first in class at Minneapolis and St. Louis, and was also sweepstakes buil at the latter show. He also headed the herd of five cows that won first place at Minneapolis and St. Louis for being the best polled herd, while at Kansas City he headed the best herd of any breed. In 1883 Knight of St. Patrick was first in class at Minneapolis, Des Moines, IKansas City and St. Louis, and sweepstakes bull at the latter show. He also headed the herd which won first at Minneapolis and St. Louis as the best polled herd, and was first at Topeka, Kan., as the best herd of any breed. Knight of St. Patrick was out of Pride of Aberdeen 10 th (3250) 355, and was a grandson on both sides of Pride of Aber- 
deen 5th 356, a daughter of the famous Paris show cow Pride of Aberdeen, shown by McCombie. Thus Knight of St. Patrick, as a result of inheritance, deserved to be a great show bull and breeder, and this inheritance he transmitted to his son Black Knight. Blackcap, the dam of Black Knight, was the most noted cow in the herd of Gudgell \& Simpson, and was a most unusual breeder. She was bred by Sir George MacPherson Grant at Ballindalloch, Scotland, and cost Gudgell \& Simpson $\$ 2,050$. Not only was she regarded as one of the very best cows in the Scotch herd, but Gudgell \& Simpson thought her the best cow by far in their herd. She was out of Blackcap of Corskie $3 \mathrm{~d}, 733$, and was four generations from Lady Ida, from whom the Blackbird tribe derived its foundress.

T. W. Harvey purchased the subject of this sketch from Gudgell \& Simpson for $\$ 2,000$, and he was taken to Turlington early in 1886 by Mr. Watson, when he began service there.

Black Knight was not purchased for the show ring, but for the breeding herd, and as a sire he made his fame. As an individual, however, he was a fine type of the breed, and is described as low, deep and thick, with back, loin and quarter covered with a thick layer of flesn most smoothly laid on. He also had a well-developed crest and a beautiful head, while as a whole he was stylish and possessed much quality and finish.

The real, transcendant fame of this bull came in 1893 as a result of the Angus show at the World's Columbian Exposition. Three daughter of his-Abbess of Turlington 9327, Progress of Turlington 7116, and Heather Bloom of Turlington 7117-were placed in one, two, three order in the aged cow class. Abbess and Progress were veritable sensations. In its review of the Angus show on this occasion the correspondent of the Breeder's Gazette wrote: "These two marvels of the cattle breeder's art can neither be adequately described nor satisfactorily delineated. The readiest of writers and the cleverest of artists may strive in vain to convey to the minds of those who have not seen the animals any clear-cut conception of their character. They are as fine and neat as they are big; as wide as they are low, as thick at the ends as in their middles, as round and full and deep and smooth as nature's laws allow in the 
cattle kind." Besides these, Heather Lad 2d 7965 , a son of Black. Knight, out of Rosa Bonheur of Turlington, at 6 years old was first in class at the Columblan exposition. This bull was bought at auction by Wallace Estill of Estlll, Mo., for $\$ 465$, and was regarded as one of the great Angus bulls of Amerlca. He became a great breeder, being the sire of Gay Blackbird 1443, third prize 2-year-old at the Columblan, a most excellent bull, and numerous others. In fact, over three-fourths of the first prize winners at the Columbian exposition were sired by Black Knight or his sons.

At the Turlington sale Wallace Estill purchased Abbess for $\$ 825$, and she proved to be a most excellent breeder. Rumor has it that Leslie \& Burwell offered the equivalent of $\$ 4,000$ for Progress, which was refused. Both of these cows were very large, welghing in show form about 2000 pounds or more each.

Black Knight dled June 20, 1891, at 8 years of age, and forty-eight hours preceding his death was in pertect health. His last calf was a bull, Proud Black Knight 16738 , calved on Oct. 26, 1891. His loss was so keenly felt by Mr. Harvey that he remarked that he would rather have sunk $\$ 10,000$ in the sea than put Black Knight under ground, for on him he based much of his success as an Angus breeder. So high were the offspring of thls bull valued by Angus breeders that during the last four years of his life eighteen helfers ranging in age from 6 to 18 months, realized an average of $\$ 425$ at public sale, while nineteen bulls of similar age averaged $\$ 300$. Among these sons were Heather Lad 2d, Guido Knight, Kelllor Knight and Keillor Finight $2 d$, all of very superior merit. At the time of Black Knight's death there were thirty helfers from 6 months to 4 years old sired by him on the farm at Turlington.

Blackcap Judy 40226, the sensatlonal first prize calf at the International Live Stock Exposition of 190u, later sold at $\$ 6,300$, the record price Angus female at public sale, was out of Blackcap 2d 4752, a full sister of Black Knight. Waterside Blackcap, another full sister, sold to Geary Bros. at public sale for $\$ 2,000$.

With the Blackbird one of the highly valued of Angus tribes, it will be clearly seen that the importance of the influence of Black Knight on the breed cannot be 
easily overestimated. Many of the most popular favorites of the show ring of today trace back four to six generations to this great sire. How shall we measure his greatness? By the opinions of men as influenced by, the character of his descendants. These, in this day, it may be fairly said, designate Black Knight "the greatest Angus bull America has produced." 


\section{THE GROVE 3D (505I) 2490}

The career of The Grove $3 d$ (5051) 2490 is full of interest because of a long life of great usefulness, one-half of which was spent in Europe and the other half in America. This bull was born on Nov. 5,1874 , on the farm of Benjamin Rogers, known as "The Grove," in Herefordshire, England. Mr. Rogers was one of England's most distlnguished breeders, and this bull was out of a cow named Blossom, by Sir Thomas, while his sire was Horace (3877), one of the epoch makers. Rog $€$ rs bred many remarkable cattle, including Sir Benjamin, Prettymaid 2d, The Grove, Bolingbroke, Sir Roger, Blossom and others.

The Grove $3 d$ did not fall into the way of the show ring. With breeding of the sort that suited the choicest tastes, and with a high degree of individual merit, he met the requirements of Philip Turner of The Leen, Herefordshire, into whose herd he went into active service, and where he remained until September, 1883, when at public sale he was purchased by C. M. Culbertson of Chicago, Ill., for 810 guineas (about $\$ 4,050$ ).

At this tlme the fame of The Grove $3 d$ was well established, and many of the best animals in the Turner sale were sired by him. The price pald by Mr. Culbertson was the highest price that had been paid for a Hereford up to that time. Rudolph (6660) 13478, a son of The Grove $3 \mathrm{~d}$, was purchased privately by $\mathrm{Mr}$. Morgan of this country for $£ 700(\$ 3,500)$. Two bull calves sired by The Grove $3 d$ sold at the sale, one at £278 5s, and another at $£ 210$.

The offspring of The Grove $3 d$ had attracted much attention, especially at the shows in Hereford and at the Shropshire and West Midland Agricultural. His heifers were a remarkable lot, and for three years in succession, beginning with 1882, Mr. Turner captured first place for the four best yearling heifers of the show at Hereford, all but one exception being daughters of The Grove 3d. These were Ethel, Beatrice, Rosina, Hawthorn, for 1882; Portia, Bertha and Nina, for 1883, 
and Kathleen, Hllda, Violet and Mllicent, for 1884 . Some of these heifers were very unusual show animals, and later praved great breeders.

This bull in Mr. Culbertson's cholce herd gave successful service for two years, when he was sold to Adams Earl, owner of the Shadeland herd, at Lafayette, Ind., for $\$ 7,000$, the record price for a Hereford for many years. When sold by Mr. Culbertson he had twelve sons and fourteen daughters of this bull on hand, with twenty-four of his best cows in calf to him.

A great risk was involved in buying at such a price at 11 years of age, but $\mathbf{M r}$. Earl recognized that The Grove $3 d$ came from a long-lived ancestry, and thought the possibilities justified. the chance. His sire, Horace, had sold at $\$ 2,500$ when 9 years old, and continued in active service till 16. Soverelgn, from whom The Grove 3d descended, was 15 years old when he sired Cotmore. uthers in the family had lived to long years of usefulness. Purchased at 11 years, The Grove 3d remained in service at Shadeland for a long period, finally dying just as he had entered his eighteenth year on Dec. 3, 1891. The infirmities of old age and the loss of his teeth caused him to gradually lose strength during the last year or two of his life, yet he gave up tenaciously, as became an old veteran. Respected in life by his owner and his falthful attendant, Uncle John Lewis, the herd manager, in the language of $\mathrm{Mr}$. Earl, his remains were "accorded a decent burial."

The writer was somewhat familia: with this great bull while at Shadeland, but it would seem appropriate to here introduce an opinion on this bull's Irdividuality as expressed by Willian Housman in Bell's Weekly Messenger, than whom there is perhaps no better critic in England. $\mathrm{He}$ is described as "having extraordinary mellowness of skin and flesh of the best kind and quality for a stock sire, the kind that increases fast; his very touch tells that under moderate pressure of keep he would be soon thick fat. He had a great growth of fine halr. The rise of the chine line over the shoulder top into the crest of the neck was particularly masculine, and the head, not coarse nor heavy, was still a bull's head. In his hind quarters he inherited from Sir 
Thomas the width immediately behind the hips and to midquarter, but did not end off so squarely as Sir Thomas did: As an old bull he was as wide and full and square and level as a moulel fat heifer." The writer might further add that he was a bull of very short leg and was a high type of a butcher's beast, with the head of a great breeding bull. In the closing days of his life one of the picturesque scenes at Shadeland was The Grove $3 \mathrm{~d}$, reclining in the lot near the barn, a dignified, veritable old monarch of the highest Hereford type.

This bull was regarded as one of the epoch-making Hereford sires. He produced a low-down, blocky, thick-fleshed type most valuable in improving the breed. Among his sons to add luster to his fame were Cassio 13352, Hesiod 11975, Hartington 4010, Rudolph 13478, Merlin 17929, Rocket 2d 26793, Hogarth 20101, Earl Grove 2d, Earl Grove 4th and Earl Grove 6th, the latter three being used in the Shadeland herd.

Soon after the death of the bull in 1891 Mr. Earl wrote to the Breeder's Gazette: "The daughters left by The Grove 3d at Shadeland sustain the reputation of the old bull as a sire. They are among the cream of the herd. * * * The prepotency of The Grove $3 d$ is manifest in every herd which has any of that blood. They have the best of quality, are easy keepers and early maturers; have splendid coats of soft, heavy hair; have plenty of constitution; are good-tempered (aside from an occasional Spartan nervousness); have splendid heads and bones, and very frequently are light in color."

An excellent picture of The Grove $3 d$ may be seen in "The History of Hereford Cattle" by Macdonald and Sinclair, and also in the Breeder's Gazette for June 25, 1885. This fittingly shows his dignity, style and impressiveness. As was well expressed by the editor of the above named journal at the time of his death: "He was one of those strikingly prepotent sires that now and then come upon the scene, one scarcely knows why or how (for breeding is not yet reduced to the point where they can be bullt to order), and that carve their names and their individuality upon the breed to which they belong in such a manner that for generations they are referred to as beasts that have helped to make bovine history." 


\section{DUKE OF AIRDRIE ( 12730$)$ 2798}

In the beautiful bluegrass region of Kentucky, a few miles west of Lexington, is Woodburn, a historic place in Shorthorn annals. Here R. A. Alexander created a great stock farm, where Thoroughbreds and Shorthorns of the very best breeding and character were produced. The herd of Shorthorns there maintained brought world-wide fame to Woodburn. Mr. Alexander had come from Airdrie House, Scotland, where was the family estate, and the bull Duke of Airdrie (12730) 9798 was bred by him on this Scotch farm, and from which he derived his name.

In the winter of 1852-3 Mr. Alexander and his brother, A. J. Alexander, visited Great Britain with the view of buying some choice Shorthorns. They selected about eighty-three head, of which fifteen were bulls. Among the cows bought was a daughter of Duchess $54 \mathrm{th}$, by $2 d$ Duke of Oxford (9046), named Duchess of Athol. This heifer and her half-brother, the 2d Duke of Athol (11376), had been bred by Colonel Towneley, and Mr. Alexander pald about $\$ 2,500$ for the pair. This heifer traced back through a line of Duchesses to Duchess 1st by Comet, and in her pedigree was the most popular Colling and Bates blood. From Duchess of Athol came Duchess of Airdrie by $2 d$ Duke of Athol or Valiant (10989), the head of this family in America. Duchess of Athol was then bred to the Duke of Gloster (11382), from which union on Aug. 4, 1854, came the bull calf Duke of Airdrie, the subject of this sketch. Along in September, 1855, - Mr. Alexander brought to America the cow Duchess of Athol and her two calves, Duchess of Airdrie and Duke of Airdrie. In this connection it is to be noted that other cattle were imported at the same time. The Alexander importations of 1853 and 1855 may be regarded as among the most important drafts of Shorthorns ever brought to America.

Duke of Airdrie, on his arrival at Woodburn, went into active service in the herd there. Later in March, 1857, he was hired by George M. Bedford of Bourbon county, Kentucky, to serve fifty cows in his herd, for which he was to 
pay $\$ 1,250$. From the Bedford hiring resulted nearly fifty calves. While in $\mathrm{Mr}$. Bedford's care Duke of Airdrie was also bred to several cows uwned by Abram Renick and Major Jere Duncan.

This bull was red and white in color, and, while a superior individual, was not a distinctly show animal. His sire, the Duke of Gioster, is referred to as a closer built, better type of buil. A. B. Alien, who was very familiar with Shorthorns in England and this country, regarded the Duke of Gloster as the most perfect type he had ever seen imported, he being brought to New York by Morris \& Becar. Duke of Airdrie inherited from his sire very superior quality of skin and hair, as well as his prominent hips and long, level, high-ciass rumps. His flanks were deep and his back very level and straight. His head was short and with strong horns and was carried with much dignity on a short neck that had a prominent crest. His shoulders were quite smooth and better than his sire's. He stood somewhat higher from the ground than most breeders of to-day desire, but his carriage was of a very imposing nature. It is said that his offspring were remarkable for their deep coior,-straight- backs, deep flanks and fine carriage. Some six months before the buli died John R. Page, the wellknown live stock artist, painted a portrait of him, from which a copy was reproduced in Sanders' "History of Shorthorn Cattle."

This Duke of Airdrie became the ancestor of many animals of high mertt, and without doubt he may be regarded as the most important sire living in America during the middle of the nineteenth century. In the American herdbook he is referred to as "the original progenitor of the American Dukes of Airdrie, called in Kentucky "The old Duke.',"

This bull is regarded as the most important factor in bringing fame to Messrs. Alexander, Bedford and Renick. Bred to Nannie Willams, a great show cow owned by Jere Duncan, he produced Duke of Airdrie 2743, an animal that proved not only a great show bull, but also a great breeder. He was a champion at local fairs in Kentucky, as well as the state fairs of Kentucky and Ohio. In 1866 , at 8 years of age, he won first prize as best aged bull at the Bourbon county fair. A son of his, Duncan's 
Airdrie 5615, was a celebrated prize winner at Kentucky and Ohio shows from 1865 to 1873 , and was a famous breeder of helfers. The Louan family, which developed in Mr. Duncan's hands, obtained great fame by the use of this Airdrie blood. The celebrated Louan show cow, Loudon Duchess 2d, resulted from William Warfield breeding Duke of Airdrie 2743 to the cow Miss Wiley 4 th.

Another and perhaps the most famous son of Duke of Airdrie (12730) was produced by mating him to the Rose of Sharon cow Duchess, by Buena Vista 299, the property of Abram Renick. From this union came Airdrie 2478. Considerable has been written in the earlier live stock periodicals about this bull, which Sanders states "may safely be listed as one of America's greatest progenitors of valuable Shorthorns." He was not a large bull, weighing 1900 to 2000 pounds in medium flesh, was red, with little white, and was not an outstanding show bull. He proved to be a great breeder of bulls. Among his best sons were Sweepstakes 6230, Joe Johnson 10294, Alrdrie 3d, 13320, Dick Taylor 5508 and Airdrie Duke 5306. All of these were promlnent as show animals in some of the best herds in the Misslssippi valley, and won many prizes. Not only that, but they also transmitted the prepotent breeding quality of the old Duke. Airdrie 2478 was almost the making of Abram Renick's herd, and his fame as a breeder not only attracted attention in England, but brought Englishmen to Kentucky to see the bull and the herd of which he was so large a part. The mingling of the Duchess and Rose of Sharon blood in Mr. Renick's herd proved a very fortunate nick. Dick Taylor, descended from Young Phyllis, was a noted sire, as well as show bull. Mated with Young Mary blood highly satisfactory returns resulted. Alrdrie Duke 5306, another son of Airdrie 2478, was bred by Abram Vanmeter and mated to Young Mary. He aiso produced very valuable helfers, of whlch Red Rose 8th, Red Rose 11th, Phoebe Taylor and Miss Washington 2d are distinguished examples. Through them in particular the fame of the Renick Airdrie blood was taken to England.

Reference has already been made to the cow Miss Wiley $4 \mathrm{th}$, by $2 \mathrm{~d}$ Duke of 
Athol, bred at Woodburn. She was purchased by William Warfield for a nelghbor of his named F. K. Hunt. She was bid off at $\$ 470$, and from her descends the Loudon Duchess tribe. Mr. Warfleld supervised her breeding, and she was bred to Duke of Airđrie (12730) at Woodburn and dropped calves by him in 1860 , $1861,1862,1863$ and 1864 , the last being a heifer, Loudon Duchess. In 1865, with Duncan's Duke of Airdrie 2743 to cover, the old Duke being dead, she dropped Loudon Duchess 2d. "These two helfers proved phenomenal show and breeding cows. The latter won fifty-six prizes at various state and local fairs in Kentucky and Ohio, and proved herself one of the great breeding and show cows of American Shorthorn history.

The influence of Duke of Airdrie, from which these varlous descendants come, is most widespread. He and his get were very extensively used on different tribes and families, and the name Airdrie met with deserved popularity. It is hardly possible to study Shorthorn pedigree as relating to American bred animals without realizing that the breeders of this country, and especially of Kentucky, are much indebted to $\mathrm{Mr}$. Alexander for the great improvement brought about through the importation of this famous bull. 


\section{IOTH DUCHESS OF GENEVA}

One of the beautiful bodies of water in western New York is Seneca lake. At its foot lies Geneva, an old town with many attractive homes along the bluff overlooking the lake. About two miles to the west, on a fair eminence, is White Spring farm. Here almost a half century ago J. O. Sheldon began the development of a Shorthorn herd by importing a number of cattle of Bates blood. Later he acquired from Samuel Thorne imp. Duke of Gloster (11382), Duchess 64th and Duchess 66th and 1st Duchess of Thorndale, daughter of Duchess 64th, and Duchess 71st, daughter of Duchess 66th. Eventually $\mathbf{M r}$. Sheldon possessed a herd of Shorthorns pre-eminently of Bates breeding, for in 1866 he bought Mr. Thorne's entire herd, at that time the leading Duchess herd in America. In 1866 Sheldon exported to England two Duchess bulls and a heifer and six Oxford heifers. This exportation was sold at auction and caused much talk on both sides of the Atlantic. Sheldon developed a great herd, and finally in 1869 sold half of it to Walcott and Campbell of New York Mills, Oneida

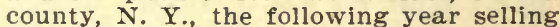
them all his remaining animals. Thus the New York Mills herd, of whlch Richard Gibson was manager, came into possession of the greatest aggregation of Bates blood cattle in America.

In this herd transferred to Wolcott and Campbell was the roan cow 10 th Duchess of Geneva. She was calved on May 15,1867 , and was sired by $2 d$ Duke of Geneva (23752) 5562 and out of 5 th Duchess of Geneva by Grand Duke of Oxford. Her sire was a bull of considerable merit that died comparatively young. However, he sired a number of animals that became celebrated in the show and sale ring. The dam of $10 \mathrm{th}$ Duchess of Geneva was a great granddaughter of Duchess 66th, while on the sire's side Duchess 66th also occurred in the line of female descent one generation further back. Tenth Duchess of Geneva was essentially a commingling of Oxford and Duchess blood on both sides, much of which for three generations back had been bred by Sheldon, 
although her grandsire on the dam's side, Grand Duke of Oxford (16184), twas bred by Captain Gunter in England. The pedigree of this cow was strikingly Bates, going back into the most famous Duchess and Oxtord blood.

Tenth Duchess of Geneva was a very beautiful cow and met largely the favor of the critics. In 1873 Wolcott and Campbell decided to hold a closing-out sale, which was held on Sept. 10 of that year. This was the most remarkable cattle sale of history, and the prices paid there have never been equaled to this day. A large gathering came together, with prominent buyers from England and various parts of the United States. The highest price of the sale was for the 8 th Duchess of Geneva, bid off at $\$ 40,600$. This cow, however, later gave birth to a dead calf and herself died soon afterward. The 10th Duchess of Geneva was also in this same sale, and the following account of her selling, as written by George W. Rust and published in Sander's History of Shorthorn Cattle, merits a place here:

"Colonel Morris of New York led with $\$ 5,000$, which Colonel King of Minnesota raised to $\$ 10,000$. Mr. Kello advanced the figure to $\$ 15,000$ for Mr. Davies, and Mr. Berwick for Earl Bective made it $\$ 20,000$, when it was very evident there was to be such a trial of nerve as had not before been witnessed. One of the Kentuckians bid $\$ 25,000$, and Colonel King added another $\$ 1,000$, which $\mathrm{Mr}_{1}$. Berwick lost no time in advancing to $\$ 30,000$. This bid Mr. Brodhead advanced $\$ 100$, when Mr. Berwick declared, 'I am done,' and started to leave the ring. His English friends, however, rallied him and he exclaimed in an excited manner, 'Thirty thousand dollars! How much is that in sterling?' One of them pushed him again to the front, exclaiming, 'Buy her and count it afterward!' but not until Mr. Kello had taken advantage of his excitement to raise the price to $\$ 30$,500. Mr. Berwick returned with $\$ 31,000$, Mr. Kello with $\$ 100$, which Mr. Berwick raised to $\$ 500$, with no other effect than to bring from his opponent a bid of $\$ 32,000$. Mr. Berwick seemed to be nettled by Mr. Kello's undisturbed manner and added another $\$ 1,000$, making $\$ 33$.000 ; and Mr. Kello, not at all dashed, added $\$ 500$ more without delay, and then Mr. Berwick advanced it to $\$ 34,000$; "and \$500,' was Mr. Kello's response. Mr. Ber- 
wick put on enough to make $\$ 35,000$ and Mr. Kello's flag and the auctioneer's hammer came down. The Americans, who had not made a bid after the $\$ 26,000$ and were aware that Mr. Kello had not been permitted to become a member of the English party, watched this contest between the two English interests with no little concern, and his opponents, although evidently feeling they had paid dearly for the victory, were in high glee that they had won it of course the price, $\$ 35,000$, would never be equaled again, and the audience gave itself up once more to various expressions of astonishment." The sale of 8th Duchess of Geneva, however, already referred to, came later.

The price paid for 10th Duchess of Geneva, however, stands as the highest one ever paid for an animal of the cattle class, where future usefulness is concerned. This cow was purchased by $\mathrm{Mr}$. Berwick for Earl Bective of Underley, England, and upon her exportation to the other side of the water that same fall she met with a most favorable reception. She remained in the herd in active service untll her death from suffocation from the pressure of an overloaded stomach on Jan. 30,1877 . It is also said her lungs were not in healthy condition at the time of her death.

When taken to England in 1873 10th Duchess of Geneva was in calf to $2 d$ Duke of Oneida (33702) 9926, and in January, 1874, she dropped a bull calf, Duke of Underley (33745), that proved a rare breeder and became very famous. The next year, in January, 1875, she had a heifer calf, named Duchess of Underley, by 2d Duke of Tregunder (26022), and twelve months later, by the same bull, she dropped another helfer, which was named Duchess of Lancaster. At the time of her death she was safe in calf to Earl Dunmore's Lord of the Isles (34630).

The oldest daughter of this covv was Sth Duchess of Oneida, and she was bred by J. O. Sheldon, and was by 4 th Duke of Geneva. She sold in the same sale with her mother at $\$ 15,300$, golng to England, into the same herd. In 1878 Earl Bective sold a daughter of this heifer at $\$ 15,000$.

In a note in the Agricultural Gazette (England), referrlng to the death of this cow, the wrlter says: "Who that has seen her ever went away without de- 
claring her the best cow he had ever looked upon?" No doubt, however, other cows have attained greater fame as breeders, but no individual has yet lived which combined so interesting a pedigree, superior individual merit, breeding worth and market value as 10th Duchess of Geneva. The added fact that she was American bred and exported to England possesses a special interest to the student, for but few American-bred Shorthorns have found their way into herds the other side of the Atiantic. A full page engraving of this cow, at 5 years old, drawn by J. R. Page, ornaments volume IX., part 2, and volume XII., part 2, of the American Shorthorn Herd Book. 


\section{ABBOTSFORD 2702 (34II)}

The bull Abbotsford 2702 (3411) was not the most distinguished specimen of the breed, yet his influence as a breeder and his family relationship were such as to make his life of very considerable interest to many Aberdeen-Angus breeders. He was bred by Mossom Boyd, Bobcaygeon, Canada, and was dropped March 2, 1884. His sire was the bull Ermine Bearer 1794 (2082), by Young Viscount, and his dam was Coquette 10th 2703 (4668), Ermine Bearer's influence has been a remarkable one, particularly in his sons. A most interesting feature of the use of Ermine Bearer is brought out in the fact that, mated with Coquette 10th, he became sire of the following bulls, they thus all being full brothers in blood:

Abbotsford 2702 .

Abavus 3625 .

Abbatoir 7402 .

Abactor 7426 .

These full brothers proved a remarkable lot in their signal importance in improving the breed. Their names are familiar in Angus pedigrees during the past twenty years. It seemed to be a most fortunate mating, this union of the sire and dam of Abbotsford.

Among the famous herds of AberdeenAngus cattle in America is that of "Heatherton," at Naperville, Ill., the property of Judge J. S. Goodwin. This herd had its inception in 1883 at Beloit, Kan., in a partnership of Judge Goodwin with his brother, W. R., Jr. After five years it was removed from Kansas to Illinois, where it stayed two years. From then on until 1902 it was in a partnership on shares between Judge Goodwin and M: A. Judy. During all these years this herd was intimately identlfied with the most progressive history of the breed. On different occasions three of the choicest Scotch bulls, champions of the first class at tre Highland and Agricultural society shows, were brought to America to be used on the Heatherton herd. This stands alone as a record in itself. These were Judige 473, "the World Beater," purchased in 1884; Justice 854, "the Incomparable," Imported in 1886, and Erica Chieftain 15498. Strangely and unfortu- 
nately each of these three great bulls lived but a short time in the Heatherton herd, and left but few offspring.

The death of Justice required that Heatherton secure another bull suited to its needs, and Judge Goodwin entered into negotiations with Mr. Boyd with the hope of securing Ermine Bearer. As this was imposslble, it was thought wise to secure his best son, if avallable. Mr. Boyd wrote Judge Goodwin that he might have the cholce of any of Ermine Bearer's sons at a price to be named by the purchaser. The telegraphed reply was: "We have twenty-nine bulls in our own barn now. Do not want a bullwant a stock getter. Will take any Ermine Bearer son at your own price if guaranteed breeder of extra stock, Abbotsford preferred." As a result of this correspondence this bull was secured. In a most interesting sketch of the Heatherton herd recently published Judge Goodwin says: "He was a thrice TrojanErica topped Ballindalloch Coquette bull, and developed into a magnificent individual, thick fleshed, a good handler and an easy keeper. But it was as the sire of a remarkable lot of animals that his fame chiefly rests, although he was practically undefeated in the show ring. * * All his calves carried such a wealth of flesh and such constitutions that to Abbotsford must be given the credit of 'making' the herd."

Abbotsford, like his sire, proved to be an unusually superior breeder of bulls, and his sons, Black Abbot 10423, Blackbird Knight 11547, Black Monk 13214, and Black Magic 14367, all obtained speclal fame for merit. Black Abbot proved also to be a great bull breeder, and Zaire 5th 13067, one of his sons, brought much fame to the Bradfute herd in Ohio, by siring some of their best animals, and especially Lady of Meadowbrook 21466, and her sister, Bertha of Meadowbrook 20275, both prize winners of the highest character. Other important sons of his were Lilburn K. 20534, Duke of Marlborough 22827 and Black Victor 24135, each of which was used at the head of prominent herds. Black Monk proved not only a great show bull, but a breeder as well. In 1897, at the Illinois state fair, the Heatherton herd won grand sweepstakes with Black Monk at its head, five of the animals in the herd also being his progeny. At 


\section{DALE 66481}

Up in north central Indiana is a little village by the name of Bunker Hill. In the eyes of the world at large it has little of interest. In the mlnds of Hereford breeders It possesses special importance from the fact that here was dropped, on Sept. 15, 1895, on the farm of Clem Graves, the calf Dale 66481, an animal that later was destined to become known as one of the remarkable individuals of the breed.

Dale was sired by Columbus 51875, a son of Earl of Shadeland 41st 33378, while. the latter was by the great Garfield 7015 (69\%5), the champion at the Royal Agricultural society show of 1882 . Lord Wilton blood is not lacking in the pedigree on the sire's side, with also Horace and Anxiety relationship present. Pet 36054, the dam of Columbus, was out of Jessie 4 th, a daughter of Anxlety 3d. Columbus proved to be a great sire, which this breeding sufficiently accounts for.

The dam of Dale was Rose Blossom 39225 , and she was sired by Peerless W11ton 12774, also a son of Garfield, and the Lord Wilton cow Peerless 10902. Peerless Wilton has sired some notable cows, among which Jessamine will always be one of the great show cows of the breed. Peerless Wilton and his daughter Jessamine were both bred by Thomas Clark of Beecher, Ill., who was also the breeder of Pet 36054 .

A thoughtful study of the ancestry of Dale shows him to have been bred in the purple, with numeruus distinguished breeding and show animals in both branches of the family. In attaining emInence in the show ring and as a sire, he but came into his rightful possession as a result of that most potent law of inheritance, that "like produces like"

The career of Dale in the show ring is one of the most remarkable experiences in Amerlcan Hereford history, and it is safe to say that it is without a parallel. In 1896 he was first in his class at the Ohio and Michigan state fairs, and also at county fairs held at Marion, Terre Haute and Portland, Ind, and at Celina, Ohio. In 1897 Dale really began to attract serlous attention. This sea- 
son he was first prize bull in his class and champlon Hereford bull at the state fairs of New York, Ohio, Indiana and Michigan. Then people began to talk and Dale's advent to a wider circuit was anticlpated with keen intérest. In 1898 he traversed a wide territory. At the New York state fair he was first in herd and champlon Hereford bull; at the Indlana state fair first in class, first in herd, junior champion, and champion in herd over all breeds; at the Illinois state falr first in 3-year-old class, senior champion and first in herd. He concluded the season's show at the Trans-Mississippi exposition at Omaha by winning first in class, first in herd and being mace the champlon Hereford bull of the show. In 1899 Dale renewed his winnings by being made champion at the New York state fair, and won first in the aged bull class at the Indiana state fair, though later he lowered his colors, when his son, Perfection, was made champion over him. At the Illinols state fair he was the aged champion Hereford bull, and was also first in class, and won second prize in the class for get of sire. Later on at the National Hereford show at Kansas City he was first in class in the stiffest competition, and also senior champion, while his son Perfection was placed first as senlor bull calf, and a daughter, Theressa, was first as senior helfer calf. At this show Dale also won the $\$ 400$ K. B. Armour silver cup as "the best bull of any age"; he was first in herd, first in the Breeder's Gazette special herd, first with cow and offspring, first in best pair of any age, and third for four of his get. Dale concluded his show yard career in 1900 , when he was made first prize aged Hereford bull at the Inciana and Minnesota state falrs, though at the $\mathrm{Na}$ tional Hereford show he was placed third. Following this, at the Internatlonal Live Stock Exposition, he was placed second in the aged bull class, in competition with seven other great bulls, including Dandy Rex, placed first; Improver, Beau Donald, Christopher and Mark Hanna. Later, however, he was made senlor champion, and thus fittingly closed his great career by winning the highest honors of the most important show of the year.

Though bred by Mr. Graves, whose wife had the honor of naming him, he was sold as a yearling to F. A. Nave of Attica, Ind., for $\$ 1,100$. In his hands 
Dale became famous through the exhibitions of 1898 and 1899 . On April 17 and 18, 1900, Mr. Nave had a dispersion sale of his entire Fairview herd at the Union Stock Yards at Chicago, on which occaston Clem Graves bought Dale for $\$ 7,500$, the highest price up to that time paid for a bull of this breed in America. After using him in his herd for some months $\mathrm{Mr}$. Graves sold Dale to $\mathbf{S}$. $\mathbf{H}$. Godman of Wabash, Ind., for $\$ 8, C 00$, who in turn sold him again in a very short time, on Jan. 8, 1901, to J. C. Adams of Moweaqua, IIl., for $\$ 10,000$, then the record price for a bull of this breed. Dale was used in Mr. Adams' herd at Woodland farm until late in 1903, when through disease said to have begun with "indigestion" he died on Oct. 18.

No Hereford bull in American history has been the subject of more sensational showing than was Dale. $\mathrm{He}$ was not a large bull, and in his best show-ring form weighed about 2200 pounds. His character as the very highest type of a meat-producing animal has never been questioned. His breadth of back, depth and spring of rib, fullness and depth of chest, development of hindquarter and length of leg, covering of flesh and quality were superb. His critics objected to his head and neck as lacking in a measure in breed character and as representing a feeder rather than a breeder. During the rounds of the great shows much twas published among the reviews regarding the mighty Dale and his strong and weak points. No Journal discussed him more critically than the Breeder's Gazette, and the writer quotes the following as representing very fairly public sentiment among competent judges.

In 1 ts report on the Illinois state fair show in 1898, says the Gazette reporter: "Dale lacks the lordly front and car. rlage of Sir Bredwell, but such perfection of body, such richness of flesh, such deep, even padding of carcass from ears to hocks is seldom seen. As a feeder's and butcher's type he is one of the greatest show bulls of any breed we have ever had in our western show yards. Criti. cism of his carcass is practically repelled. $\mathrm{He}$ is filled, loaded, furnished, packe 1 with prime beef at every polnt; thick meated without being rough, rich bit not gaudy. Such wealth of thlck cutting ribs and loins, such hip covering, such smoothness and all around symmetry of body, such balance of parts fore and aft, above and below, might 
be looked for in vain at all the barns." At the end of the 1899 season this same journal, referring at length to Dale, says: "The longer the ribbons hold out the heavier grows his burden of first and championship awards. His victory in this class was but the beginning of triumph unlque and falrly unparalleled. Never were honors heaped in such abundant measure with so little protest from the opposition. One by one his critics were sllenced. Dale left the show the Dewey of the Hereford campalgn of 1899."

Dale dled a comparatively young bull, and consequently we cannot measure his deepest influence on the breed. His son Perfection 92891, however, now owned by G. H. Hoxle of Thornton, Ill., has won the highest champlonshlp honors in the American show ring. Bred by Mr. Nave, he was sold in his dispersion sale to Thomas Clark of Beecher, Ill., for $\$ 1.300$, in whose herd he dld valuable service. On the dispersal of Mr. Clark's herd, on Jan. 7, 1902, Mr. Hoxie purchased Perfection at auction for $\$ 9,000$. Another son of Dale, known as Perfection ¿d, is now in service in the Hoxle herd. He is an Individual of much merit. presenting the essentlals of his sire in conformation, and much is anticipated from his herd service. At Mr. Nave's dispersion sale in 1900 there were sold ninety-six head for a total of $\$ 64,415$. Of the antmals sold the following were sons and daughters of Dale, with the prices affixed: Perfection, \$1,300; Perfectlon 2d, $\$ 950$; Lelax, \$400; Theressa, $\$ 3,000$; Sister Theressa, \$1,000; Beatrice, \$750; Lady Wilton, \$420, and Favorite Flower, \$250.

Dale has passed over the great divide and it $w i l l$ be many days before the American show ring again sees his equal as an individual. As the sire of Perfection alone he is entitled to lasting honors, and no doubt in the future will he become more and more firmly established in the esteem of the Hereford fraternity as a notable breeding as well as show buil. 


\section{GAY MONARCH 92411}

Among the most prominent breeders of Shorthorn cattle in America is the firm of J. G. Robbins \& Sons of Indiana. For many years and including three generations has this famlly lent its great influence in promoting Shorthorn interests. In the fall of 1887 Luther Adams of Storm Lake, Iowa, made a choice importation of Shorthorns from Scotland, and on May 16, 1888, a draft from this importation was sold at auction in Dexter Park at Chicago. In this consignment was the roan bull Gay Monarch 92411. About this time the Robbins family was searching for a suitable bull to head their herd. Becoming favorably impressed with Scotch blood as shown in prominent Indiana herds it was considered desirable to visit Dexter Park in advance of the sale and search for what was wanted. Two young bulls in the collection met with favor, Lord Lieutenant, a red and white Secret, and Gay Monarch, the roan. The latter being more stocky and thicker fleshed, finally found most favor and was bid oft at the sale to Robbins \& Sons at $\$ 375$.

Gay Monarch 92411 was bred by W. S. Marr of Upper Mill, Tarves, Scotland, and was calved Jan. 26, 1887. He was sired by William of Orange 95736 (50691) and had for dam Alexandrina 17th by Athabasca (47359). The sire of Gay Monarch was one of the great bulls of Scotland, A. H. Sanders pronouncing him the best individual seen by him in 1892 when visiting Great Britaln. He was bred by Amos Cruickshank at Sittyton, and later found extensive use in the Marr herd. $\mathrm{He}$ was a massive, thick-fleshed, deepbodied bull of very superior quality, belonging to the Orange Blossom tribe. Athabasca, the sire of Gay Monarch's dam, was a half-brother of the celebrated Field Marshall, and was himself sire of Sign of Riches, the first-prize Highland and Agricultural society buli at Glasgow in 1897, later sold to go to South America at a long price. On his dam's side Gay Monarch descends from Alexandrina by Alaric (21155) through six generations of that name-viz., $4 \mathrm{th}$, 5 th, 9th, $14 \mathrm{th}^{\circ}$ and $17 \mathrm{th}$, besides the original dam. 
In 1900 , referring to their early career with this bull (Breeder's Gazette, Aug. 1, 1900), the Messrs. Robbins wrote:

"When Gay Monarch arrived at our farm he was severely criticlsed for being heavy in the horn, crooked in the hind legs and drooping in the rump. Many other defects were found by those selfconstltuted critics who came to see him, but we took him to our county fair (Decatur county, Indiana) and there he had to take second place, being beaten by Prize Cup, a red Young Mary bull bred by Colonel Moberly, whlch could almost stand astraddle of our little, short-legged bull. At Seymour, Ind., however, we fared better, having a judge who had respect for short legs, and he gave him his class ribbon and the championship, too. As a 2-year-old he was turned down in class at-Terre Haute, but by another judge awarded the championship, and the rest of the season (1889) was a winner. As a 3-year-old he came out a hard bull to beat, and his calves were with him, winning as well as he, and from that time until he was retired from the shows his history is pretty well known, as he was only shown at the best shows of the country, and his winnings are a matter of history."

In a sketch of Gay Monarch it will be appropriate to refer to his more important show ring record. Perhaps his first appearance in a really great fair was in 1889 as a 2-year-old at the Indlana state falr, where he met no competition in class, but was received with much favor. Up to this time he had won fourteen prizes. He passed over the prominent 1890 circuit, coming out again at the Indiana show in 1891, where in the aged bull class he was placed second, William Warfield being judge. At the same show, however, he was later made sweepstakes bull over all beef breeds, but not by the same fudge. In 1892 he was made first-prize aged bull at the Ohio and Indiana state fairs, showing at the latter place against Young Abbotsburn. This is the only instance in which Gay Monarch defeated Young Abbotsburn, and this award was not in accordance with the evidence. These two great bulls met on various occaslons In the show ring, and the general consensus of opinion was that the latter was the superior show animal of the two. This same season Gay Monarch was sec- 
ond at the Illinois state fair, with Young Abbotsburn flrst. During 1892 he won eleven first and one second prizes, while his get won $\mathbf{1 5 6}$ prizes in all, there being tiventy-one of his progeny on exhibition in the shows. In 1893 Gay Monarch reached the maximum of his show-ring fame by his record and that of his get at the World's Columbian exposition. Here in aged buil class he was placed second to Young Abbotsburn. These two bulis were of the same general type, but Gay Monarch, with all his excellence, could hardly equal his great rival, lacking somewhat in substance and flesh. As a breeder, however, Gay Monarch fairiy surpassed the Moberly bull. Here at this show he won the championship for the best herd over all beef breeds, a great tribute to his high worth, the herd consisting of himself and the cows Gay Mary, Nora Davis, Lady Verbena and Nancy Hanks. In Shorthorn competition only, this herd won third place, however. In the Shorthorn class of the best four animals of either sex under 4 years old, the get of one sire, the Robbins got fourth place with Gay Mary, Nora Davis, Peeriess and Nancy Hanks, ail daughters of Gay Monarch. Gay Mary was given the first place in aged cow class, and also won sweepstakes as the best female of any age in Shorthorn classes, and was also sweepstak€S aged cow of all breeds. Nora Davis won fourth place in the 2-year-old class, and Nancy Hanks, her own sister, won third place in the heifer calf class. Nora Davis and Nancy Hanks were, also placed fourth in the competition of "two animals, either sex, from one cow," they being from the cow Nora, by Enterprise 41901.

Among the sons of Gay Monarch none received so great honors in the show ring as Monitor 109140. He was famous as a campaigner, and won many first prizes in severe competition, being. $r \in-$ peatediy champlon at Indiana and Illinois state fairs, and winning a total of about 100 prizes in various shows.

To Gay Monarch is credited the winning of twenty-six first prizes in class, twenty-six sweepstakes, six second priz $\in$ s and twenty-four times heading the winning herd.

This bull was of the typical low-down, deep-bodied, short-legged, thick-fleshed sort, with a superior amount of quality. 
He was red roan in color, with a rich, mellow hide, and was smooth, broad and deep, and in show ring form weighed 2600 pounds. His disposition was superb, and he seemed to transmit this quality to his offspring, notably so to Monitor.

Gay Monarch lald the foundation of the success of the Robbins' herd. Other great bulls succeeded him, as, for example, St. Valentine 121014, and The Lad for $\mathrm{Me}$ 140618 , but Gay Monarch has been considered by many to have been one of the greatest Scotch-bred bulls ever in service in America. The showing of his offspring has really been remarkable. At one time forty of his sons and daughters were in show herds in the United States, and his get have been widely distributed over America from ocean to ocean. Among his progeny may be mentioned Gay Mary, Gay Rose, Gay Miss, Gay Maggie, Gay Belle, Gay Victoria, Gay Lady, Gay Violet, Gay Nellie, Gay Ellzabeth, Gay Abbotsburn, Gay Harry, Gay Victor, Gay Knight, Gay Dewey, Gay Monarch 3d, Gay Monarch 4th, Monitor, Bright Monarch, Nora's Monarch, Secret Victor, Lancaster, Lavender Monarch, Straight Monarch, Lucy Lee, Rosebud, Crescent Kate, Verbena 2d, Lucretia, Sunflow $\in$ r, Sultana, Red Lady, Model, Touch-MeNot, Peerless, Modest Girl, Nora Davis, Jenny Grey, Lustre, Nancy Hanks, Model, Monarch's Lady 2d and Miss Ramsden 5th of Oakland. Among these are many show and breeding animals of v£ry great merit.

Gay Monarch died on Aug. 2, 1899, aged 12 years, and to-day what was once mortal of this famous old bull lies under a mound of earth, which is fittingly crowned with a neatly inscribed monument erected to his memory by his appreciative owners on the farm so long the scene of his activity. Should the Robbins of Horace continue in the future, as in the past, to carry the standard of the red, white and roans, this stone and its associations can but inspire them to greater efforts, with the reward, it is to be hoped, of even greater future success. 


\section{CORRECTOR 48976}

The name of Sotham is a prominent part of Amerlcan Hereford history. The first Herefords were brought to America by Henry Clay in 1817, and in 1839 William H. Sotham, English by birth, American by adoption, began to advocate this breed. For many years Sotham did yeoman work for the Hereford breed as importer, breeder and general promoter. In time his mantle very naturally fell to his son, T. F. B. Sotham, who has ranked among our greatest breeders up to the present time. At Chlllicothe, Mo., on Weavergrace farm, Mr. Sotham during the past ten years has developed a herd of Herefords that has contained many animals of the breed now well known to fame.

Among the bulls owned at Weavergrace was Corrector 48976.. He was calved on Jan. 9, 1891, and died Dec. 5, 1902 , almost 12 years old. The influence of this bull on the Sotham herd and American Hereford interests was so profound that it is but fitting that something of his breeding, career and influence should receive the attention of the Hereford student.

Corrector had for sire Harold 21141, an imported bull that in the late ' 80 s made a creditable show ring record, and that also slred a number of other males and females of merit. On his sire's side Horatius was grandsire and old Horace great-grandsire, while Regulus was the sire of Harold's dam, and he was by Sir Roger, Coral 13526, the dam of Corrector, was a great breeding as well as show cow, she being the dam of Franklin, Conqueror, Prince, Royal Wiiton, Archibald A., Royai Grove, Jr., and Beaubois. Her eight calves are said to represent a genuine value of $\$ 50,000$. She had De Cote (3060) for grandsire on both sides, known as a famous sire and show bull. Coral, like Harold, is descended five generations from Sir Thomas, a royal winner and breeder of the first rank.

Though shown to some extent, Corrector cannot be classed among the great show bulis of the breed. He first appeared as a calf in 1891, when he won second prize in class at the International 
fair and exposition at Detroit, second prize at the Michigan state fair and first prize at the Ohio state fair at Columbus. This year at St. Louis he was in the second-prize lot of four animals the get of one sire. In 1892 Corrector was the third-prize yearling at the De. troit International fair and exposition, was first prize in class at the Darke county (Ohio) fair at Greenville, and at the state fairs of Ohio and Indiana, and second prize at the St. Louis exposition. He also headed the first-prize young herd at Columbus and Indianapoilis, and was in the group of four receiving second prize as get of one sire at St. Louis. In 1892 he was known as a promising yeariing. In 1893 he was first in the 2-year-old Hereford class at the Iowa state fair, first at the northern Missouri district fair at Chillicothe and champion at the head of the herd over all breeds at the same show, was first prize at Trenton, Mo., second prize at the St. Joseph exposition and was second prize in herd at the St. Louis fair. Finally, in 1894, he was champion buil, any age. over ail breeds at the northern Missouri district fair at Chilicothe.

The real strength of the story of Corrector lies in the character of his offspring. Had it not been for these the world would never have heard much of this bull. This was a great breeder. but more especialiy of bulls. He was of impressive carriage, with proud bearing and graceful crest, and a head of much character. His offspring are notable for their impressive fronts and breed characteristics as shown in head and horn. Corrector was strong, broad and well sustained of back, as are many of his descendants, with heavy fleshing qualities and a superior covering of hair. Prominent among his sons may be mentioned Cadillac, Checkmate, Chillicothe, Chorister, Emperor, Exemplar, Goodwin. Grandee, Harold, Prince Laurel, Photograph, Protection, Sir Bredweli, Sir Comewell and Thickset. Of his daughters Benefice, Benita, Choke Cherry. Ecstasy, Florimel, Gallatea, Genevieve, Georgina, Goiden Lassie, Grace, Happiness, Hebe C., Lady Bredwell, Lady Brenda, Lady Charming, Lady Plushcoat, Nannette, Peace and Pure Gold are noteworthy.

It would occupy too much space to chronicle the winnings of these and other sons and daughters of Corrector, 
but some of the more noteworthy are entitled to a place here. Sir Bredwell 63685 and Thlckset 68685 have met with the most popular favor in the show ring of any of Corrector's sons, and each was a grand specimen of the breed. Each of these won many prizes at the most prominent American shows. However, in 1898 at the Transmississippi exposition, Sir Bredwell was first prize aged bull, while Thickset was the second prize 2year Hereford bull. At this same show Sir Bredwell, Thickset, Benefice 78825 and Silence 83690 won first place as four best animals, get of one bull, whlle Sir Bredwell and Benefice won first as produce of one cow, they having Beatrice 8036 for. dam. In 1899 Sir Bredwell sold at auction for $\$ 5,000$ to Colonel C. C. Slaughter of Texas. Thlckset had a rather remarkable show ring record and was repeatedly made first in class and champion bull at great shows. At the Iowa state fair in 1898 he was champion Hereford bull any age, and sentor champion at the Minnesota state falr. In 1899 at the Illinois state falr he was second in class, but was champion over all breeds at the Minnesota state fair the same season. In 1900 he was sold at auction for $\$ 5,100$ to William Humphrey of $\mathrm{Ne}$ braska. Thickset was a wonderfully smooth bull of considerable size and very superior type and was first shown as a calf in 1896. Protection 58568 is another famous show animal by Corrector, having won many prizes of the first class in the shows of 1895 and 1896. Sir Comewell 68776 won prizes in 1896 at the Minnesota, Iowa and St. Louis shows, and later in 1899 sold at auction for $\$ 1,600$. Grandee 78839 won various prizes at the shows of 1898 and 1899, and sold at auction March 1, 1900, at $\$ 1,500$. Exemplar 63671 , shown with success at the Minnesota, Wisconsin and Illinols state fairs in 1895 , sold the next year at auction at $\$ 500$ and later at $\$ 1,550$. In 1899 Checkmate 93981 was successfully shown at the National Hereford show and at the Iowa and Minnesota state fairs.

Of the daughters of Corrector much might be sald. They possessed much style and carried broad backs, deep ribs and represented the best type of the breed. Benefice 78825 was champion over all breeds at the Minnesota state fair in 1899; Benita 58542, the dam of the famous Benison 64017 , has a long string of 
prizes to her credit; Lady Charming 63672 is not only a champion show cow, but a successful breeder, being dam of Clarissima; Grace 58553, the dam of Exemplar, tvas one of the most beautiful and suc-" cessful show daughters of Corrector.

One of the most impressive methods of demonstrating the breeding value of an animal is shown in the results of the sales of his offspring. So far as the writer is a ware, no bull in America has given such financial showing in his get as has Corrector. From 1894 to 1903, inclusive, 104 Corrector bulls sold for $\$ 45$,520 , and 85 females for $\$ 32,920$, a total of $\$ 78,440$, an average of $\$ 415$ each. The highest price pald for any one of these was $\$ 5,100$ for Thickset. From 1894 up there is an interesting and gradual increase in the yearly average price received for these Corrector animals, a striking tribute to his worth. A peculiar feature connected with the sale of these cattle is that, with two exceptions, they wore all sold at public auction in annual cales held by Mr. Sotham, thus constituting a record unique in American cattle history. In a personal letter to the writer Mr. Sotham says: "A considerably better showing could be made if the prices received for Corrector cattle sold by other parties was included in this table. For instance, I sold the heifer Happiness for $\$ 1,050$ to Clem Graves, who resold her for $\$ 2,650$. I sold the bull Sir Comewell to Grant Hornaday for $\$ 840$, who resold him for $\$ 1,600$, and I might multiply a great many cases where hundreds and even thousands of dollars were made on the subsequent sale of Corrector's get."

A fine double page colored plate of Corrector, reproduced from an oil painting by J. W. Hills, the well known live stock artist, lllustrates the Breeder's Gazette for March 30, 1898, while a smaller one of the same is a frontispiece in a treatise on Hereford cattle published by $\mathbf{M r}$. Sotham. Miller's "History of Hereford Cattle" also contains a colored copy of this same picture.

A careful survey of the facts must demonstrate the remarkable prepotency of Corrector and the great value of his blond to Mr. Sotham and the Hereford breed. America has not lacked for great Heroford breeding and show bulls, and certainly Corrector stands at the forefront an honor to the breed and his breeder. 


\section{YOUNG ABBOTSBURN 1 I 10679}

In 1874 Joseph Thomson of Whitby, Ontario, Canada, imported a Shorthorn cow known as Village Bud. She was bred by Amos Crulckshank at Sittyton and was sired by Scotland's Pride (25100) of Cruickshank breeding. This cow was in calf at importation to Ben Wyvis (30528) and in Thomson's sale she brought $\$ 925$, being bought by J. \& W. B. Watt of Salem, ont. In their possession she dropped a roan heifer calf which was named Village Blossom. She developed into a thick-fleshed, broad-backed, lowdown sort and found much favor later in prominent Canadian show rings. In 1883 J. I. Davidson had imported a bull named Abbotsburn (47312) 106090 , bred by Cruickshank, which the Watts purchased and bred to Village Blossom, and on March 2, 1885, she dropped a roan bull calf which was named Young Abbotsburn 110679.

A little further reference to the ancestry of this calf is here desirable. His sire, Abbotsburn, was by Roan Gauntlet, one of the really great Scotch sires, also the sire of Field Marshal (47870), bred by Cruickshank and later owned by William Duthie and also used for some time in the herd of Queen Victoria at Windsor. Ben Wyvis, the sire of Village Blossom, was by Caesar Augustus (25704), a prize winner on the other side of the wat $€$, while Butterfiy's Joy, the dam of Ben Wyvis, is descended from the Towneley Butterfiys, a tribe of Shorthorns that has produced many prize winners. On the dam's side Young Abbotsburn traces back to Picotee, by Premier (6308), a cow of much character that at 10 years of age was a first prize cow at Aberdeen. Plcotee was a daughter of Sunflower, by Unicorn (8725). This pedigree of the subject of thls sketch presents very strong Crulckshank breeding on both sides, while the records show that he is descended from many great prize winners.

When about 7 months old Young Abbotsburn was purchased for $\$ 200$ by Alexander Norrie of Paisley, Ont., an excellent judge of cattle, who owned him for four years. In his possession he was 
shown at local fairs as a yearling and 2year-old, and met with considerable favor. He was used in his herd and others in the neighborhood and bred well. Although the Messrs. Watt had not speclally regarded this bull as of unusual promise as a calf while in their herd, rumors later came to them of his considerable merit. Norrie had given him good care, and when he sold out in 1889 the Watts attended the sale and purchased Young Abbotsburn. About this time Colonel $T$. S. Moberley of Forest Grove herd, Richmond, Ky., was casting about for a bull to head his herd that would be of the very highest show type. He made a trip to Canada in 1890, where he saw this bull and purchased him for $\$ 425$, believing that he had found not only a breeder, but also a show animal of great possibilities. Soon after his purchase Colonel Moberley was asked what he was going to do with him, to which he responded: "Use him a little and show him 'right smart.'"

The first appearance of Young Abbotsburn in the show ring on this side of the line occurred at the Detrolt International Exposition in September, 1890. Here he' was shown as a sort of "dark horse," as it were, his name not being given out to the public, and so he was referred to as "the great unknown." His high character was at once seen at this show, where he won first in class. The next week at the Michigan state fair at Lansing he was first in class. In continuing the circuit that season he was first in class at the state fairs of Ohio, Indlana and Illinois, winning the grand sweepstakes at the latter show, over all beef breeds, competing against the Hereford Cherry Boy and the Angus Errant Knight, both show bulls of the first class. Young Abbotsburn was the sensation of the season, and well the writer remembers his appearance on the fair grounds at Indianapolis and tlee talk caused thereby.

Young Abbotsburn soon demonstrated that he was the most remarkable Shorthorn show bull that America had seen in a generation, if not more. At Peoria he vanquished without trouble Cupbearer (52692), who for several years had been invincible. No aged bull of any sort seemed capable of winning the coveted prize for which this champion com- 
peted. In 1891 he was first in class and sweepstakes aged bull, over all beef breeds at the state falrs of Iowa, Minnesota and Illinois, not showing elsewhere on the circuit. In 1892 he was first in class at the Iowa state fair at Des Moines. first in class, and winner of grand sweepstakes at Nebraska state, second in class, yet winner of grand sweepstakes at Indlana state, and first in class and winner of grand sweepstakes at the Illinois state falr at Peoria. In 1893 Young Abbotsburn was at the head of Colonel Moberley's herd at the World's Columbian Exposition at Chicago, where he was declared the best aged Shorthorn bull, the best Shorthorn bull of any age and the grand sweepstakes bull over all beef breeds, with Anclent Briton, the Hereford champior, placed next below him and Gay Monarch third. Here closed the show yard career of this great bull, defeated but once in the United States and then in competition with Gay Monarch, judged by Joseph Rlppey, a local Indiana Shorthorn breeder, whose judgment on this occasion received no support excepting from partisan or superficlal observers. The real judges of the ringside, not lacking in regard for the high merit of Gay Monarch, knew that bad judgment had been displayed on that occasion.

Laudation of the hlghest sort was bestowed on this champion in his day, and it is doubtful if much of it was overdrawn. No animal as an individual is perfect, yet Young Abbotsburn presented much that must be recognized as found in the ideal beef type. He was massive in form, weighing up to 2800 pounds, broad, deep, square at ends, thick and full at flanks, broad in the chest, thick in hind quarter, short of leg and in his prime very smoothly covered with a great layer of flesh and hide of most superior substance and quality. In a slight degree he lacked in breed character, yet he was not open to important criticism on this account. He did have, as he was, a distinctive feeder's head. He stood square on his feet, a monument of living flesh, a feed lot model. In spite of his great weight Young Abbotsburn was unusually active on his feet for such size. In March, 1894, the writer, with a party of live stock students, paid a visit to Richmond and to Colonel Moberley's farm. In the inspection of the stock Young Ab- 
botsburn came in for the llon's share of attention, as might have been expected. Finally when through, in reply to the question, "How active is he?" Forbes, the herdsman, heading him down the lane, took the strap he had been holding him by and slapped him over the rump, upon which he trotted off down the lane with astonishing lightness and ease, a surprise to all present.

In commenting on the character of this bull A. H. Sanders, one of the ablest Shorthorn students living, wrote at the time of Young Abbotsburn's death: "As a feeder's type Young Abbotsburn has probably had no peer in this generation. Possessed of great scale, an iron constitution, digestive and assimilative powers of the highest order, and traditional Cruickshank depth of $\mathrm{rlb}$ and shortness of leg, he developed under skillful feeding into the heaviest buil of his height known to American Shorthorn records. Other bulls have had as good backs, other bulls have had ribs that sprung with more perfect arch, and other bulls have shown more perfect breeding character in their heads, but when it came to depth and fullness at all the special feeding points, the bulging neck velns, the low, heavy flanks, the generous middle piece, the thick, wide twist, and the placid temperament, the old bull never had nor does he now leave a rival. As a feed lot pattern Young Abbotsburn measured up to the highest standards set by Mr. Cruickshank."

In the summer of 1894, Colonel Moberley, most unfortunate for Shorthorn interests, was drowned at Virginia Beach, Va., while nobly rescuing his daughter from a watery grave. His death resulted in the selling of the Forest Grove herd at executor's sale on Oct. 23, 1895, when Young Abbotśburn and four of his sons and seventeon of his daughters were disposed of with the rest of the herd. The old bull was nurchased by T. J. Wallace of Bunceton, Mo.. for $\$ 475$, in whose possession he remained until Feb. 4, 1898, when he died.

Young Abbotsburn had been soniething of a disappointment as a breeder, yet he sired a number of animals of much merit. His daughter, Mary Abbotsburn 7th, in the hands of Aaron Barber of New York, proved to be one of the greatest show cows of the latter part of the nineteenth century. She made her first appearance in 
the show ring in 1892 , as a calf, when she won first place at Des Moines in a ring of fourteen. For years she had a remarkable show ring record. Mary Abbotsburns 1st, $2 d$ and 4 th were also cows of merit and winners in the show ring. A son of Young Abbotsburn named The Corker, out of May Belie, by 2d Duke of Hillsdale 51071, was purchased by $T$. R. Westrope \& Son at the dispersal sale for $\$ 500$. Extreme financial depression alone at the time of the Moberiey sale is no doubt the cause for the low prices secured. At the death of Young Abbotsburn it is said there were eight bulis and thirteen heifers by $\mathrm{hlm}$ in the Wallace herd. This herd was disposed of on May 17, 1900 , at Kansas City, by public sale, when nine of hls sons and daughters sold for $\$ 2,075$, an averaige of $\$ 230$ per head. Two sons, Sir Abbot 128850 and Butterfly Abbotsburn 144508, that have been referred to as of much excelience, were catalogued for the sale. Four days prior to its occurrence Sir Abbot suddenly died, while the other son was purchased at $\$ 600$ by J. H. McCunlough of Dayton, Mo.

The career of Young Abbotsburn in the show ring was all the most ardent could have wished for. As a breeder, however, he did not meet all expectations. With a pedigree of merit, carrying the blood of many prize winners, it was reasonable to look for the transmission of his many good qualities to his offspring. That he did not so transmit them to a notable extent may be due to his high condition of living and show ring career, or to yet other factors which we are unable to comprehend. Yet a record of nearly twenty years shows but few noteworthy animals descended from Young Abbotsburn besides Mary Abbotsburn 7th. In spite of this fact he will always be entitled to a place among the really famous bulls of the breed. 


\section{LADY OF MEADOWBROOK 21466}

Many a beautiful cow has been graced with the title of Lady. The history of the English show yard and breeding herd records more than one Lady of fame, among which might be mentioned Lady Fragrant, Lady in Waiting, Grand Lady, Lady Sarah and Red Lady, while in America Lady Charming, Lady Plushcoat, Lady Superior and yet others are among the elect. $\mathrm{On}^{\circ}$ this side of the Atlantic, however, no individuai of the bovine race is better entitled to this name than the Aberdeen-Angus cow Lady of Meadowbrook 21466.

Lady of Meadowbrook 21466 was bred by D. Bradfute \& Son, Meadowbrook farm, Cedarville, Greene county, Ohio, and was calved on Dec. 9 , 104. Her sire was Zaire 5th 13067, a son of the well-known Black Abbot 10423. Zaire 5th for some ten years was a prominent prize winner at the great shows in the United States and has repeatedly been referred to as one of the greatest of the modern show and breeding Angus bulis, for he has sired many most excellent animals. He was short of leg, broad of back, square and full both in front and behind, and was heavily fleshed when in good condition. At this writing, eariy in 1904, Zaire 5 th is still in active service in an Ohio herd at the age of 15 years.

The dam of Lady was Lavender of Meadowbrook 15697 , a cow of much merit that won many prizes, including first in aged class at the Ohio and Illinois state fairs in 1898. As a 5-year-oid she weighed 1900 pounds and possessed a beautiful front, unusually fine top and bottom lines, with a wealth of flesh smoothly laid on. She was known on the circuit as an extra fine cow. Lady of Meadowbrook is three generations descended from $\mathrm{Ab}$ botsford 2702 on the sire's side, while on the dam's side she goes back to imp. Lovelock 4 th 6046 , a prize winner at the Ohio state fair, as grandam, with Lovelock 2889 as great-grandam and Lavender 2890 as great-great-grandam.

As a calf Lady of Meadowbrook did not particulariy attract attention, and at the New York state fair in 1895 she was third in the Angus calf class, being also third 
at the Illinois state the same season. At this stage of her development she was referred to as "very sweet and chunky."

As a yearling the writer can find no record of Lady being shown, but as a 2-year-old in 1897 she was third in class at the Illinois state fair, while she was also placed higher up in other fairs this season, in which she met no opposition outside the local herd. This season she was shown along with her dam, with which she was often compared, she having her mother's full bosom, great spring of rib, full flanks, deep twist and great size. In 1898 Lady of Meadowbrook began to show her true colors. She was classed as the best Aberdeen-Angus female in class at the state falrs of Indiana, Wisconsin and the St. Louis exposition, and was made champion cow of the breed at Wisconsln and St. Louis shows. She was placed second to her mother in class at the Illinois show at Peorla. This same season, in 1898, the Bradfute herd invaded Kentucky to compete for the class and herd championships at the Shelbyville show. This was the first Aberdeen-Angus exhibit south of the Ohio river. The Bradfutes had carefully considered making this trip, as it meant an invasion of Shorthorn territory of the most pronounced type. A committee of Shorthorn men acted as judges, and during the bull competition the Shorthorns had the advantage.

When the female classes came on a sensation occurred with the entrance of Lady of Meadowbrook into the ring. Her outstanding merit was at once recognized and she was made first prize winner. The 2-year-old and yearling prizes were won by Shorthorns, whlle a Bradfute helfer calf won first in class. In the llning up in the herd competition great excitement prevailed, for only Shorthorns had heretofore won beef herd prizes in this section. The superior excellence of the Bradfute cattle, with the great Lady of Meadowbrook at the head of the female classes, would not be downed, and amid much excitement and applause the Aberdeen-Angus herd was made champion.

In 1899 Lady of Meadowbrook was first-prize and champion cow at the Ohio, Wisconsin and Indiana state fairs and the St. Louis show, and was first in class at the Illinois state fair. At the 
latter show she was defeated for championship by Lucia of Estill, a smaller type of cow, and of much merit, yet lacking the scale and thickness of flesh of Lady.

In 1900 Lady of Meadowbrook made her last campaign in the show ring, winning first in class at the Ohio, Wisconsin, Indiana and Illinois state fairs and the St. Louis exposition. She was also made champion cow at the Wisconsin, Indiana and St. Louis shows. At this time she weighed about 2000 pounds. At the International Live Stock Exposition in December she was made champion Angus cow, but as she did not deliver a live calf within the specified time the prize money was refunded according to the rule. At the time, however, nobody questioned her right to win. Thus closed the show yard career of what is unquestionably one of the greatest American-bred Aberdeen-Angus show cows that has been seen in America. Her merit was unquestioned. She was more often than not judged by men of other breeds, and they never failed to recognize her merit. One year when she was made grand champion cow at the Indiana state fair at Indianapolis a committee of three placed the ribbonsconsisting of George Allen and J. $\mathbf{H}$. Pickrell, Shorthorn breeders, and David MeKay, of Gailoway affiliations. When the judges' book was being signed $\mathrm{Mr}$. Pickrell, one of America's most distinguished Shorthorn authorities and then secretary of the American Shorthorn association, stepped up to the cow and said: "I want to sign my name with the book lying on the back of the best cow I ever saw."

In some of the shows where Lady was shown'she had for company some of the famous females of other breeds, of which Ruberta, the Shorthorn queen, and Dolly 5 th of Hereford fame are fitting examples.

As a breeder Lady of Meadowbrook has not been a fallure, neither has she been the success anticipated. She has had but one daughter, Lady $2 d$ of Meadowbrook 36954 , which was the firstprize 2-year-old heifer at the Pan-American Exposition at Buffalo. Lady had one bull calf which was lost through no fault of hers. She carried another five months and lost it.

Lady of Meadowbrook still resides upon the farm of her birth, along with 
three sisters of merit. She refuses to thin down and reduce to desirable breeding form, but serves as a living model of how a high-class breeding and show cow should appear. She has brought much of fame to her breeders and to the breed, and it is to be hoped that she may yet leave a legacy to Meadowbrook that will add still greater laurels to their well-known herd. 


\section{SCOTTISH STANDARD (6488) \\ 15221}

The Galloway is one of the rather $1 \mathrm{~m}$ portant beef breeds of cattle that is eomparatively little known outside of Scotland. These cattle were first brought to America and to Canada perhaps fifty years ago, and about 1870 were brought into the United States. Not, however, until within a comparatively few years has the breed really attracted attention, whlle our cattle literature and live stock journals give one but scanty information concerning the Galloway from any point of view. Five years, however, have seen a change, and to-day in the Mississippl valley and far west Galloway cattle are receiving gratifying attention. Yet from the historical point of view Amerleans know little of Individuals of this breed.

Scottish Standard (6488) 15221 was bred by C. Graham of Harelawhill, Canonble, Scotland, and was calved on April 5, 1895. His sire was The Pathfinder 3d (5991), while his dam was Gentle Rose 2d (13029). The Pathfinder 3d not only. bred some very fine animals, but was himself a first-prize winner at the Highland and Agricultural Society show and the Royal of England and some others. Camp Follower (5042), the sire of the dam of Scottish Standard, is one of the famous names among prize-winning Highland and Royal show Galloway sires. Baroness 2d of Tarbreoch 21280, the first-prize aged Galloway cow at the 1902 International Live Stock Expositlon and at the 1901 Highland show, was a daughter of his. Dora of Durhamhill (13550), by Camp Follower, was a cham pion at both Highland and Royal shows. Louisa $2 d$ of Durhamhill i14925), another daughter, won the breed championship and gold medal for the best Galloway at the 1898. Highland show. Scottish Farmer (6628) was also a prize-winning son and champion.

Scottish Standard was imported by Brookside farm, J. H. Bass, proprletor, Fort Wayne, Ind, in 1899. Before exportation he had not only sired some great show animals, but had also won the following prizes in Scotland and England: In 1896, as a yearling, he was first at the Carlisle bull show, and also 
at the Castle Douglas Agricultural show. In 1897 he wwon first prizes at Castle Douglas, Dalbeattie, Scotland; Highland and Agricultural society of Scotland at Glasgow, and the Royal Agricultural Soclety of England show at Manchester. At the two latter shows he was also awarded medals for being the best Galloway bull exhibited. In 1898 Scottish Standard was. placed first at Castle Douglas, the Dumfries Union, and at the Highland and Agricultural at Kelso, Scotland; also at the Royal Agricultural Society of England show at Birmingham. He also won medals at both Highland and Royal shows. In 1899 he again won premier place at Castle Douglas and the Royal Agricultural Society of England at Maidstone, winning a medal also at the latter exhibition. This same season he was imported to America to head the Brookside farm herd.

In the United States this bull has not been extensively shown. In 1901 he made a number of the more important state fairs, but was not in the best flesh, and so did not obtain the coveted first place. At the Indiana state fair he was placed second, at the Illinois state third and at the International Live Stock Exposition at Chicago also third. His chief competitors on this circuit were the imported bulls Druid of Castlemilk 17054 and Muscosis 3d. Scottish Standard was not presented in as high flesh and bloom as his competitors, and so did not secure the recognition he might have won otherwise. Scottish Standard showed himself to be a level-backed, blocky, deep-bodied, short-legged, grand-headed type of the breed, covered with a beautiful coat of hair. Good critics this season counted him the best type of the three bulis mentioned, each of which was of unusual excellence and international reputation. The Breeder's Gazette correspondent, reviewing the International Galloway show, wrote: "No attempt has been made to finish him for this competition, and yet the grand type of the bull, his head of outstanding character, his closeness to the ground and his finish warrant the honors he has attained and qualify him for any contest for which he may be prepared."

Before his importation to the United States, Scottish Standard began to show his worth as a breeder, although his show-ring career was of great eminence. His son McDougal 4th of Tarbreoch 18300 
(6841), out of Maggie of Tarbreoch (8613), was imported to this country in 1900 , where he obtained great distinction in the show ring on many occasions and sold at auction in Chlcago at $\$ 2,050$-the highest price ever paid for a Galloway in America. At the 1901 International McDougal 4 th of Tarbreoch stood second, one place above his sire, in the aged bull class.

In his great value as a sire Scottish Standard stands as the greatest Galloway bull that has yet lived in America, and no doubt as one of the most prepotent of the breed in any land. The importance of this great bull as a breeder can be in part seen in the following show yard record of his progeny in the United States. Scottish Standard 1st 18538 is perhaps his greatest son. In 1901 he was the first prize Galloway bull calf at the Indlana and Illinols state fairs and fourth at the International. As a yearling, in 1902, he won first place at the Wisconsin, Indlana, Iowa and Minnesota state fairs and at the International Live Stock Exposition, and was also junior champion Galloway bull at these shows. In its revlew of the Iowa state fair Galloway show, referring to Scottish Standard 1st, the Breeder's Gazette said: "Brookside boasts one of the greatest sires known to the breed in old Scottish Standard, but if he had never begotten another calf than this one under praise he would have lived in history. **** of Galloway type and character this fellow is fully master; he has ample scale, grand levelness, remarkable width and strength of back and fine condition. When he fills a llttle about the tail head, as he probably will, there will be as few flaws to pick in him as any representative of the breed that ever stood before the publlc on this side the water. Such sweeping compliment does not often find record in these columns; it appears only when the facts warrant it." In 1903 Scottish Standard 1st was first prize 2-year-old Galloway bull at the Indiana, Illinois, Minnesota and Iowa state fairs, and at the Kansas City Royal show and at the International Live Stock Exposition. In these shows he was also champion. McDougal 4th of Tarbreoch is also a worthy son of Scottish Standard. In 1901 he was second in class at the International and in 1902 first prize aged and chainplon at Wisconsin, Min- 
nesota and Indiana state fairs, and second at the International Exposition. Professor Thomas Shaw is credited with saying at the Minnesota state fair that he was "one of the best types of the breed he ever saw." The cow Scottish Princess 1st 19335 is one of Scottish Standard's greatest female descendants. At the 1901 International she won flrst prize in class and champion female." In 1902 as a yearling at the state fairs she was placed third at Wisconsin, second at Indiana, first in class and junior champion at Minnesota, and was third at the Iowa state fair. This season she won four blue ribbons and four junior championships. In 1903 she was first prize 2-year-old Galloway cow at the Illinols state fair and was given third place in class at the International Exposition. She is a female of great beauty and superior breed type.

Scottish Mist 19771, another daughter of Scottish Standard, as a helfer calf in 1902 either stood first or second in class at all the fairs, and in 1903 she divided honors with Scottish Princess 2d 20965, her half-sister, for first place at the shows. In 1903 a popular favorite was Adelia of Brookside 22716, a heifer calf by Scottish Standard, she boing made first prize winner in class and junior female champion at the leading fairs. In 1902 Standard -Yet 19776 appeared as a bull calf in the ring and he proved very successful. Two-In-One 19755, another son, in 1903 made a creditable show as a yearling.

Scottish Standard has proven very fertile as a breeder, and the Brookside herd has relied largely on him for its show yard winnings. From a personal letter to the author from Brookside farm the following is quoted: "In the fall of 1903 we took with us to the following fairs eleven calves, sired by Scottish Standard; the fairs were at Des Moines, Iowa; Hamline, Minn.; Springfield, Ill.; Indianapolis, Ind.; American Royal at Kansas City and the International at Chicago. At these shows we with our eleven calves won forty-seven first prizes, twenty-four second prizes, eighteen third prizes, seven funior championships and one grand champlonship. *** We will state that the animals we showed this fall were all Scottish Standard calves, Scottish Standard 1st being our 2-year-old, Two-In-One our yearling bull. Scottish 
Challenger our bull calf, and, besides these, Scottish Princess 1st, Scottish Mist, Scottish Maid 19768, Scottish Princess 2d 20905, Scottish Empress 22715, Scottish Jewel B. 22723, Adelia of Brookside and Betty Miller 18356. Repeatedly Brookside farm was awarded first prize on our four animals, get of one sire, and on various occasions they won both first and second places with his sons and daught $\in$ rs in groups of four."

Scottish Stanoard is yet alive, with possibly several more years or service. There are many of his daughters now in the Brookside herd, and the possibilities of his progeny to secure still greater Galloway fame is beyond estimation. It is highly probable, however, that future Galloway records in America will be remarkably impressed with the blood of this great buli. It is doubtful even now if the offspring of a single bull of any breed in so short a time has made so strong a show ring record as has Scottish Standard.

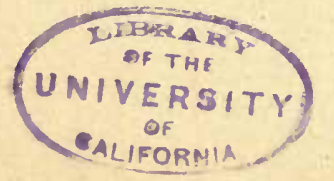


UNIVERSITY OF CALIFORNIA BRANCH OF THE COLLEGE OF AGRICULTURE

THIS BOOK IS DUE ON THE LAST DATE STAMTPED BELOW

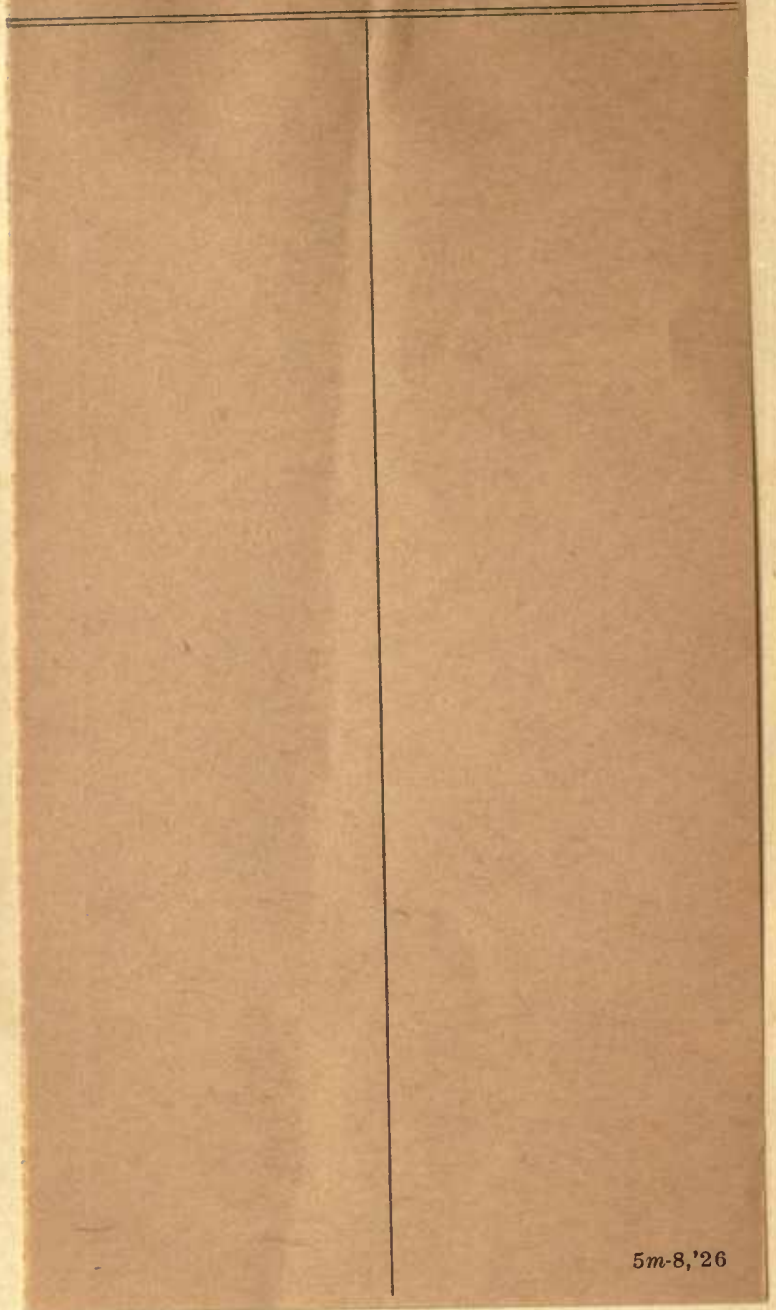




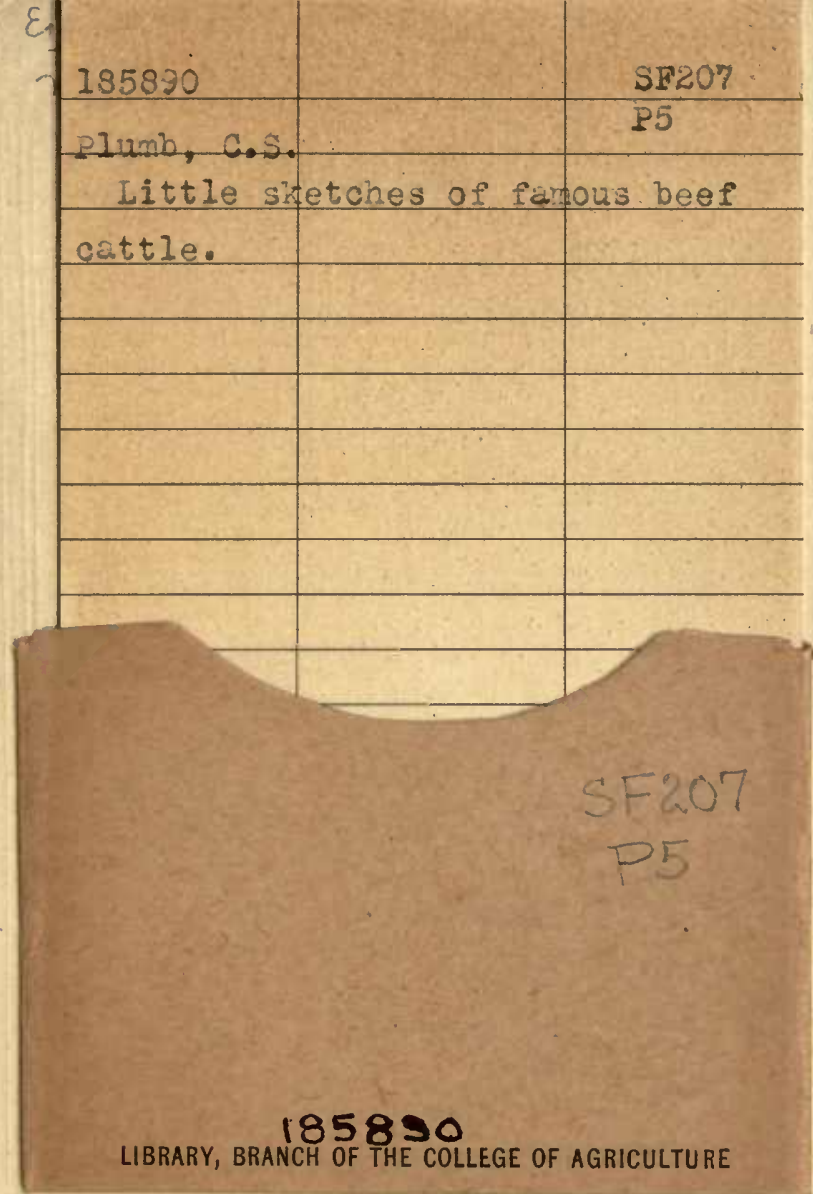


